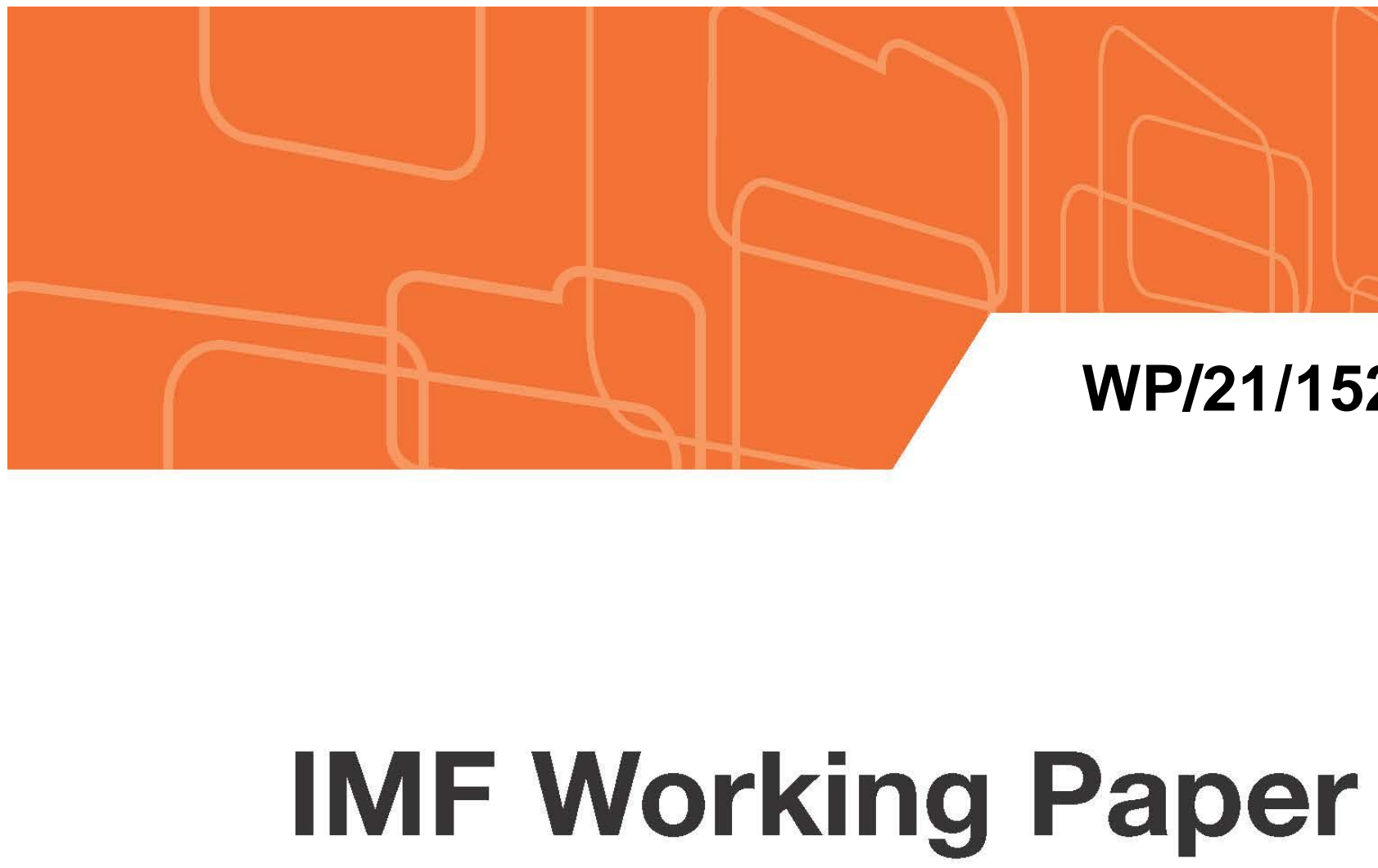

\title{
Do Lenders Make Less-Informed Investments in High-Growth Housing Markets?
}

by Sophia Chen, Lev Ratnovski and Yangfan Sun

IMF Working Papers describe research in progress by the author(s) and are published to elicit comments and to encourage debate. The views expressed in IMF Working Papers are those of the author(s) and do not necessarily represent the views of the IMF, its Executive Board, or IMF management. 


\title{
IMF Working Paper
}

Research Department

\section{Do Lenders Make Less-Informed Investments in High-Growth Housing Markets?}

\author{
Prepared by Sophia Chen, Lev Ratnovski and Yangfan Sun \\ Authorized for distribution by Maria Soledad Martinez Peria
}

May 2021

\section{IMF Working Papers describe research in progress by the author(s) and are published to} elicit comments and to encourage debate. The views expressed in IMF Working Papers are those of the author(s) and do not necessarily represent the views of the IMF, its Executive Board, or IMF management.

\begin{abstract}
Nonlocal mortgage lenders with greater exposure to high-growth housing markets accept fewer loan applications in these markets and experience greater stock return volatility. When these lenders expand to high-growth markets, they also ration credit to a significantly greater degree than when they ex-pand to other markets. Mean-variance analyses show that nonlocal lenders' exposure to high-growth markets is associated with more risk, more efficiency, and more return on mortgage portfolios. Overall, these results imply that expansion to high growth markets leads to a decline in screening and riskier investment by nonlocal lenders, which may reflect a risk-return tradeoff in their portfolio strategy.
\end{abstract}

JEL Classification Numbers: G11, G21, R31

Keywords: Portfolio, Mortgage, Housing Markets, Risk Assessment

Author's E-Mail Address: ychen2@imf.org; lev.ratnovski@ecb.int; ys383@ georgetown.edu

\footnotetext{
${ }^{\mathrm{i}}$ The views expressed are those of the a uthors and do not necessarily represent IMF, its Executive Board, or its management, norECB.
} 


\section{INTRODUCTION}

Lenders can rely on private or public information to screen mortgage applicants. Private information allows lenders to measure and price risk more accurately, but collecting private information is costly because it requires lenders to acquire and evaluate customized measures of credit quality like local default rate. In comparison, public information like credit score is less costly to obtain and can be more easily used with standardized risk-pricing formulas for lenders to scale up lending. As a result, lenders that expand beyond their primary local markets may have fewer incentives than local lenders to collect private information and hence make less-informed investment decisions (Stein 2002; Berger et al. 2005; Liberti and Mian 2009). In this paper we ask whether such lending behavior is consistent with evidence surrounding the expansion of mortgage lending by U.S. banks in the past two decades and whether a lower level of screening may have contributed to riskier mortgage lending in some local markets that experienced acute housing cycles.

By answering these questions, we aim to connect two important features of the U.S. housing market during this period. The first is a large-scale geographic expansion of mortgage lending by U.S. banks. In 1995, local lenders - those with over half of their lending in a single local market - originated 11.5 percent of mortgages. The market share of local lenders declined to 4.3 percent before the $2007-2008$ crisis. It rebounded after the crisis, then declined again, reaching 7.3 percent in 2017 (Figure 1). The second feature is the historic boom and bust in housing prices that occurred around the time of the crisis in 2007-2008. The housing cycle was most acute in high-growth markets - such as Sand States (Arizona, California, Florida, and Nevada) and areas with low land availability for housing development such as Miami, FL and New Orleans, LA - where mortgage lending increased dramatically during the boom and collapsed after the crisis. For example, the share of mortgages to Sand States increased from 31 percent in 1995 to 40 percent in 2005. It then fell to 25 percent in 2010 before a gradual recovery (Figure 2). Not surprisingly, the share of lending by nonlocal lenders in high-growth areas follows the same boom-bust cycle. As total lending to high-growth areas increases, so does lending by nonlocal lenders and vice versa (Figure 3).

Using both public signals and private information to screen mortgage applicants should allow lenders to evaluate applications based on a broader set of information than public signals alone and hence accept a higher proportion of the applications conditional on public information. Thus, market expansion, coupled with a lower 
level of screening, will lead to more credit rationing. To the extent that private information allows lenders to price risks more accurately, we also expect market expansion to lead to higher ex post risk for the lenders. Although these arguments are in principle applicable to the expansion to any markets, they are particularly relevant for expansion to high-growth markets because rapid expansion to these markets makes lenders less likely to invest time and money in collecting private information. Based on these arguments, our empirical tests exploit variations in mortgage acceptance rates and lenders' risks associated with expansion to high-growth markets from a comprehensive data of mortgages from 1995 to 2017.

In our first test, we compare the mortgage acceptance rates of lenders with different exposure to high-growth markets. We find that exposure to high-growth markets is associated with lower acceptance rates by nonlocal lenders in these markets, consistent with a lower level of screening by these lenders.

To examine whether these variations in acceptance rates are driven by lenders' incentives to invest in private information, we explore an exogenous shift in lenders' incentives resulting from a discontinuity in the eligibility of loans for guarantees from government-sponsored enterprises (GSEs: Fannie Mae and Freddie Mac). The willingness of GSEs to purchase mortgages based on a prescribed set of underwriting criteria reduces lenders' incentives to collect private information to screen loans that are eligible (i.e., conforming loans) compared to loans that are ineligible (i.e., jumbo loans) 1 Consistent with this argument, we find that the negative effect of the highgrowth market lending share on the acceptance rate is much stronger for jumbo loans than for conforming loans.

We then test whether lenders behave differently when they expand to high-growth markets. Those within-lender regressions exploit variations of the same lender in different markets, allowing us to account for all cross-lender variations, cross-market variations, and time-varying lender-specific shocks using lender $\times$ year fixed effects and market fixed effects. Therefore, we can attribute the variations in acceptance rate to differences in lender behaviors in different markets. We find that lenders approve significantly fewer loan applications in peripheral markets than they do in primary markets. Such credit rationing is more pronounced for peripheral markets in high-growth areas. In other words, when lenders expand to high-growth mar-

\footnotetext{
${ }^{1}$ GSEs are restricted by law to purchase single-family mortgages with origination balance below a specific cutoff, knows as "conforming loan limit". Loans above the cutoff are jumbo loans. The national conforming loan limit was $\$ 417,000$ for 2006 -2008.
} 
kets, they ration credit significantly more than when they expand to other markets. Furthermore, lenders accept significantly fewer applications in the jumbo segment than they do in the conforming segment. The rationing of jumbo loans is also more pronounced in high-growth areas.

Can these results be driven by greater selectivity among lenders in high-growth markets? If they are more selective in high-growth markets, they ought to perform better and experience lower risk. If, in contrast, they invest less in private information for screening and risk assessment, they will be unable to price risks as accurately and thus perform more poorly and bear higher risk. We therefore examine how exposure to high-growth areas affects lender profitability and risk. We find that such exposure is associated with higher stock volatility for nonlocal lenders but not for local lenders, consistent with the notion that nonlocal lenders in high-growth markets engage in a lower level of screening instead of exercising greater selectivity. Evidence of profitability is mixed, likely reflecting a subtle tradeoff between lenders' risk and return. Evidence of systemic risk seems inconclusive, possibly because of small sample size.

Our next test further explores the risk return tradeoff for lenders by examining the performance of their mortgage portfolio. This test is also beneficial because it does not rely on equity-based measures of risk, which may reflect a lender's business unrelated to mortgage lending. Specifically, we test whether exposure to high-growth areas affects the risk, return, and efficiency of the mortgage portfolio. To do so, we first construct the mortgage portfolio of each lender using geographic information on the mortgages it originated and kept on the books. We treat loans in the same local market as a single asset in the portfolio. This approach abstracts from the heterogeneity of loan return and risk in the same market and allows us to focus on portfolio composition across markets.

Using a mean-variance analysis for the mortgage portfolios, we find that exposure to high-growth markets is associated with higher portfolio risk, corroborating our earlier evidence from stock return volatility. We also find that higher portfolio volatility is accompanied by higher portfolio efficiency and higher portfolio return. This risk-return tradeoff suggests that the higher risk associated with expansion to high-growth markets may reflect portfolio strategy of lenders: they are willing to accept higher risk in exchange for higher efficiency and higher return.

We close our analyses by showing that our findings are not tales of the past. Al- 
though the crisis of 2007-2008 is now in the past, the boom-bust cycle is not. Since the trough in 2010, lending in high-growth areas has recovered. The share of lending to Sand States has since grown at a rate faster than during the runup to the crisis, surpassing the precrisis peak by 2016 (Figure 2). Housing prices in Sand States have also soared from the postcrisis trough, reaching nearly the precrisis peak by 2017 (Figure 4). Our findings on a lower level of screening and higher risks associated with the expansion to high-growth markets continue to hold in the post crisis period of 2010-2017. These findings alert us to the danger associated with ill-informed investment during a new housing boom in high-growth areas.

Our paper is related to substantial literature on the housing cycle around the 2007-2008 crisis. Our results corroborate previous findings showing that deterioration in lending standards has contributed to the housing bust following a crisis (Mian and Sufi 2009; Keys et al. 2010; Dell'Ariccia et al. 2012). Although most of the previous literature focuses on subprime markets, our results suggest that less-informed decisions by lenders associated with their geographic expansion of mortgage lending constitute an important supply-side factor that may have contributed to higher risks in lenders' prime mortgage portfolios. Compared to previous findings based primarily on metropolitan statistical areas (MSAs) over the precrisis period, our findings are more broad-based, covering nearly all zip codes in the US over a period of 23 years, pre- and postcrisis.

Our paper is also related to a sizable literature on the real estate exposure of lenders. Although mortgages may not be high-risk loans during normal times, they may have severe implications for lender risks during a downturn. Because housing prices are highly correlated with the business cycle and across geographic areas, lenders often experience difficulty with liquidity in mortgage portfolios during a downturn 2 Several recent studies point to the important linkage between bank risk and real estate exposure. Altunbas et al. (2017) show that banks with higher real estate exposure exhibited higher risk during the crisis. Chakraboty et al. (2018) show that before the 2007-2008 crisis, banks reallocated their lending capacities to bubbly housing markets at the expense of other borrowers. We complement these papers by highlighting lenders' less-informed lending in high-growth housing markets as a contributing factor to lender risks related to real estate exposures.

Our paper is furthermore related to the literature on the geographic expansion of

\footnotetext{
${ }^{2}$ For discussions on risks associated with real estate exposure, see Favara and Imbs (2015), Jorda et al. (2015), Mian et al. (2017), and Calomiris and Chen (2020).
} 
mortgage lending. Prior to the 2007-2008 crisis, geographic expansion was considered by many commentators to be a means to diversify local mortgage credit risks.$^{3}$ The crisis suggests, however, that it may have been ineffective in delivering on the diversification promise because of correlated housing markets (Cotter et al. 2015) and uninformed investment associated with diversification. Loutskina and Strahan (2011) show that compared to concentrated lenders-lenders that make the most loans in one local market - diversified lenders focus less on the information-intensive jumbo market and ration credit more. They also show that diversified lenders have lower profits and worse stock market performance during the crisis. Our results complement theirs by showing that expansion to high-growth areas is a particularly risky form of geographic diversification, associated with lower profitability and higher risk for the lenders. We further complement these results with additional direct evidence of the risk and efficiency of lenders' mortgage portfolios.

On the effect of geographic expansion on bank risk more generally, extant empirical evidence is mixed. ${ }^{4}$ Demsetz and Strahan (1997) find that better diversification does not translate into reduction in risk because banks operate with higher leverage. Acharya et al. (2006) find that diversification does not guarantee greater safety for banks because of less effective monitoring. In contrast, Deng et al. (2007) associate geographic diversification with value enhancement and risk reduction. Goetz et al. (2016) exploit variations resulting from the removal of interstate branching regulation and find that geographic expansion lowers risk by reducing exposure to idiosyncratic local risks. Our paper contributes to this literature by offering new evidence of the positive link between mortgage diversification and lender risks.

The rest of the paper is organized as follows. Section 2 documents evidence of mortgage loan screening. Section 3 presents results of lender risk. Section 4 discusses mortgage portfolio risk. Section 5 describes evidence from the postcrisis period and concludes.

\footnotetext{
${ }^{3}$ Geographic diversification as a risk-mitigation strategy was discussed, for example, in the Freddie Mac 2007 Annual Report and in the 10-Ks of many real estate investment trusts (REITs).

${ }^{4}$ The theoretical prediction is also ambiguous. Geographic diversification may hedge against idiosyncratic local risk according to portfolio theory. Theories based on agency costs suggest that lenders that concentrate on local markets may be better able to collect private information and price local risks (Stein 2002; Berger et al. 2005; Liberti and Mian 2009).
} 


\section{EVIDENCE FROM MORTGAGE LOAN AC- CEPTANCE}

\subsection{Data and measurements}

We build our datasets from a comprehensive loan-level sample of mortgage applications and originations collected by the Federal Reserve under a provision of the Home Mortgage Disclosure Act (HMDA). Under this provision, all regulated financial institutions, including commercial banks, savings institutions, credit unions, and mortgage companies, with more than $\$ 30$ million in assets are required to report their house-related lending. HMDA covers close to 95 percent of mortgage originations in the US. The comprehensive coverage of HMDA offers an advantage over other datasets on housing-related lending, which focus on securitized loans. The comprehensiveness of HMDA is key to characterizing lenders' geographic presence.

HMDA data provides information on mortgage originating institution, loan size, and applicant characteristics, including income, gender, race, and ethnicity, as well as information on the detailed location of the property, the year of loan application, and whether the application was accepted. As we will show, this is the key information we rely on to construct a picture of lenders' presence in local market over time. To ensure the comparability of our mortgage sample, we restrict the sample to conventional loans by excluding loans guaranteed by the Federal Housing Administration, Veterans Administration, Farm Service Agency, or Rural Housing Service. We also restrict to loans for the purpose of single-family home purchase and exclude loans for refinancing or home improvement.

We define local markets at the 3-digit zip code level. This geographic unit is a good measure for local markets because it usually delineates geographic areas that are well-aligned with local housing markets, such as county or a few contiguous counties. In urban areas, 3-digit zip codes also align well with metropolitan statistical areas (MSAs), which usually encompass a city and surrounding areas with close economic ties (see Appendix Figure A1 for examples of 3-digit zip codes and MSAs). Our final dataset covers 880 local markets out of 882 3-digit U.S. zip codes. Compared to most literature on the geography of mortgage, which focuses on the MSA level, this dataset offers the advantage of characterizing high-growth and lowgrowth markets as well as lenders' geographic presence in the most comprehensive way. We will return to the definition of the geographic market in our robustness tests. 
We also collect lender-level data by merging HMDA with the Report of Condition and Income ("Call Reports") based on the identification of reporting institutions in each filing year. We merge the two data by linking the Call Report identification number with the HMDA identification number.

For housing prices, we use the quarterly house price index produced by the Federal Housing Finance Agency (FHFA). This index measures house prices in 3-digit zip codes using appraisal values and sales prices for homes purchased with conforming mortgages.

\section{Summary statistics}

The raw HMDA sample contains 485 million applications over the 1995-2017 period. After dropping applications to lenders not included in the Call Reports (those not reporting to the Federal Deposit Insurance Corporation, Federal Reserve, and Office of the Comptroller of the Currency) due to the lack of data on lender characteristics, and loans with missing data on loan characteristics, property location, and applicant characteristics, we are left with a sample of 362 million mortgage applications.

Table 1 reports summary statistics on applicant characteristics and mortgage acceptance for conforming and jumbo loans. In the conforming segment, 20.9 percent of the applicants are women and 3.6 percent are members of minority groups. The average acceptance rate is 87 percent by loan number and 88.2 percent by loan volume. Lenders on average originate $\$ 190$ million of loans per year and keep 45 percent of them on their balance sheets.

In the jumbo segment, the percentages of female and minority applicants are 9.6 and 2.1 percent respectively. The acceptance rate for jumbo loans is 90.3 percent by loan number and 90.4 by loan volume. Lenders on average originate $\$ 79.4$ million mortgages and keep 80 percent of them on their balance sheets.

In our sample, the mean and median of lender size are $\$ 2.4$ billion and $\$ 206$ million respectively, suggesting that most lenders are small institutions. The average exposure to Sand States (constrained areas) is 10.5 (6.2) percent of total loans.

\section{Housing cycle in high-growth markets}


In our analyses, we distinguish between high-growth markets - local housing markets with highly cyclical patterns - and other markets. We use two alternative definitions of high-growth markets. One is the Sand States: Arizona, California, Florida, and Nevada 5 The other is geographically constrained areas with low availability of land for development. The use of land availability to measure constraints to housing development was pioneered by Saiz (2010) and is widely used to explain housing cycles ${ }^{6}$ Saiz (2010) developed a land availability index for 269 MSAs with population of 50,000 or more from satellite data by excluding geographic constraints to housing development resulting from either a steep slope (e.g., mountainous land) or bodies of water (e.g., oceans, lakes, rivers, wetlands). Lutz and Sand (2019) extended the Saiz (2010) index to all 3-digit zip codes and counties in the contiguous United States.7 We define zip codes at the bottom decile of Lutz and Sand (2019) index as constrained areas.

Figure 2 shows that the volume of mortgages in high-growth markets followed with a strong precrisis expansion and a rapid postcrisis collapse. The share of mortgages originated in Sand States increased from 31 percent of the total in 1995 to 40 percent in 2005, collapsing after the crisis to as low as 25 percent in 2010 before a recovery. The share of loans to constrained areas followed a very similar trend albeit of a smaller magnitude.

Figure 4 shows that house prices in high-growth markets are also highly cyclical. House prices grew by 103 (51) percent in Sand States (constrained areas) in 2001-2005, compared to the national average of 44 percent In 2008-2010, house prices in Sand States (constrained areas) collapsed by 27.8(10.5) percent, compared to the national average of 8.7 percent. Postcrisis, house prices in high-growth markets again grew faster than the national average. Prices in Sand States (constrained areas) grew by 6.3 (3.1) percent in 2011-2017, compared to the national average of

\footnotetext{
${ }^{5}$ The term was used by the Federal Deposit Insurance Corporation (FDIC, 2009).

${ }^{6}$ The Saiz (2010) index has been used in the literature to proxy house price cyclicality based on the observation that housing supply in more geographically constrained areas is less responsive to housing demands or house price movements (see, for example, Mian and Sufi 2011; Mian et al. 2013; Charkraborty et al. 2018).

${ }^{7}$ Lutz and Sand (2019) also differ from Saiz (2010) in technical aspects. Each geographic area is defined in the former by a geometric polygon plus a 5 percent buffer and in the latter by a $50 \mathrm{~km}$ radius around the polygon's centroid. Thus, the former covers the entire polygon (plus buffer); whereas the latter likely misses peripheral areas of large polygons. Despite their difference in methodology, the Lutz and Sand (2019) and Saiz (2010) indexes are highly correlated with a correlation of 0.8 and $R^{2}$ of 0.7 .
} 
2.6 percent.

\subsection{Acceptance rate in high-growth markets}

In our first test, we compare the mortgage acceptance rate of lenders with different exposures to high-growth areas. We estimate the following regression:

$$
Y_{i j t}=\alpha+\beta \text { HighGrowthShare } \text { Sijt-1 }+\lambda X_{i j t-1}+\mu_{t}+\epsilon_{i j t}
$$

where $i, j$, and $t$ index lender, loan segment (conforming or jumbo), and year, respectively. $Y$ is acceptance rate, defined as accepted applications as a share of total applications. The share is calculated based on the number of applications or loan volume. HighGrowthShare is lending to high-growth markets as a share to total lending. We control for year fixed effects and a vector of lender characteristics and applicant characteristics, $X$, including lender size (measured by the logarithm of total assets), Tier 1 capital ratio, deposit-to-total assets ratio, lender diversification, the average income of applicants, the percentage of applicants who are women, and the percentage of applicants who are minority. Lender diversification is an index that measures a lender's overall level of mortgage diversification. This index is measured as 1 minus the sum of squared shares of mortgages in all markets in which the lender operates, and it ranges from zero (for lenders that lend to a single market) to nearly 1 (for lenders that operate in many markets).

In this simple setup, we can compare the acceptance rate for lenders with relatively high and low exposure to high-growth markets. If lenders with high exposure to high-growth areas accept fewer applications, we expect a negative relationship between high-growth market exposure and acceptance rate $(\beta<0)$.

We then test the following regression:

$$
\begin{aligned}
Y_{i j t}=\alpha & +\beta \text { HighGrowthShare }_{i j t-1}+\gamma \text { HighGrowthLender } \\
& +\delta \text { Hight-1 }_{\text {LrowthShare }}{ }_{i j t-1} \times \text { HighGrowthLender }_{i j t-1} \\
& +\lambda X_{i j t-1}+\mu_{t}+\epsilon_{i j t}
\end{aligned}
$$

where HighGrowtheLender is an indicator variable, which takes value 1 if a lender's mortgage loans to high-growth markets exceeds 25 percent of its total mortgage loans 8 Equation (2) sharpens the identification of equation (1) by allowing

${ }^{8}$ The distribution of high-growth lending share (Figure A2 in Appendix) clusters close to 0 or 1. Our results are robust to alternative thresholds of 20,33.3, or 50 percent. 
the acceptance rate to vary with exposure to high-growth markets depending on a lender's primary market location. It thus distinguishes between lenders that primarily serve high-growth areas and those that serve high-growth areas as peripheral markets. This distinction helps us to rule out alternative interpretations of our results - a point to which we will return. If lenders that expand to high-growth areas as peripheral markets ration credit more than local lenders in these markets, we expect a positive coefficient on the interaction term $(\delta>0)$.

Table 2 reports the results for equation (1). We find that lenders that are more exposed to high-growth markets have significantly lower acceptance rates. The results are robust to defining acceptance rate by the number of loans (columns 1 and 3) or by loan volume and to defining high-grow markets by Sand States or constrained areas. The difference in acceptance rate is not driven by borrower characteristics. The estimates without (columns 1 and 2) and with (columns 3 and 4) controlling for borrower characteristics are very similar. The estimated effects are economically large. If a lender's lending share to Sand States increases by 1 standard deviation (28.4 percent), the model (Panel A column 3) suggests that the likelihood of the rejection of a loan increases by 10 percent (from 13 to 14.4 percentage points) in the conforming segment. The effects are higher in the jumbo segment. In this case, the model (Panel B column 3) suggests that a 1 standard deviation increase in a lender's lending share to Sand States increases the likelihood of the rejection of a loan by 17 percent (from 9.7 to 11.3 percentage points).

A comparison of Panel A and B shows that the negative effect of a high-growth market lending share on acceptance rate is stronger for jumbo loans than for conforming loans. What can explain this difference between the two loan segments? One explanation is that the willingness of GSEs to purchase conforming mortgages reduces lenders' incentive to invest in private information for conforming loans for all lenders. This GSE effect, however, is absent from the jumbo segment because jumbo loans do not conform to the GSE purchase criteria.

Table 3a reports the results of equation (2) for conforming loans. We find a negative relationship between exposure to high-growth markets and the acceptance rate for nonlocal lenders. The result is again robust to the definition of high growth market and applicant controls. The coefficient of high-growth market exposure and the high-growth market lender dummy is positive with a magnitude that offsets the standalone term of high-growth market exposure (with a negative sign). This suggests that exposure to high-growth markets has a negligible effect on the acceptance 
rate for local lenders in high-growth markets.

These results also hold for jumbo loans as reported in Table 3b. For nonlocal lenders in high-growth areas, high-growth exposure is significantly negatively correlated with acceptance rate. As shown in Table 2, the effect on jumbo loans is larger than that on conforming loans: 212 percent and 131 percent for the high-growth market defined as Sand States and constrained areas, respectively. The estimated effects are also economically large. For example, if a lender's lending share to Sand States increases by 1 standard deviation (28.4 percent), the model (Table $3 \mathrm{~b}$ column 3 ) suggests that the likelihood of the rejection of a loan increases by 58 percent (from 13 to 20.6 percentage points).

The distinction between local and nonlocal lenders in high-growth markets provides useful insights. First, if credit rationing in high-growth areas occurred only because lenders accept fewer applications in peripheral markets, then we would expect the acceptance rate to increase in high-growth exposure among high-growth market lenders. We do not observe this for high-growth market lenders, suggesting first, that credit rationing is unique to nonlocal lenders serving in high-growth markets; and second, that lenders may behave differently in their peripheral markets than in primary markets. We next examine this cross-market difference more closely.

\subsection{Within-lender tests}

We perform a within-lender test and compare the acceptance rate of the same lender in different markets. This test addresses two important questions. First, could our results so far be driven by unobserved heterogeneity across lenders? For example, lenders that have less comparative advantage to scale up may concentrate on nonhigh-growth areas. Second, do lenders behave differently in different markets?

We estimate the following regression:

$$
\begin{aligned}
Y_{i j k t}=\alpha & +\beta \text { PrimaryMarket }_{i k t}+\gamma \text { Jumbo }_{j}+\delta \text { HighGrowthMarket }_{k} \\
& + \text { PrimaryMarket }_{i k t} \times \text { HighGrowtheMarket }_{k} \\
& + \text { _Jumbo }_{j} \times \text { PrimaryMarket }_{i k t}+\psi \text { Jumbo }_{j} \times \text { HighGrowthMarket }_{k} \\
& +\lambda X_{i j k t}+\mu_{i t}+\epsilon_{i j k t}
\end{aligned}
$$

where $i, j, k$, and $t$ index lender, loan segment, (3-digit zip code) market, and year, respectively. $Y$ is acceptance rate. PrimaryMarket is a dummy variable that 
takes a value of 1 for a lender's primary market, defined as the market with the highest lending volume. HighGrowthMarket is a dummy variable for Sand States or constrained areas. Because our previous results show a difference between jumbo and conforming loans, we include a dummy variable for jumbo loans (Jumbo). We include the same vector of lender and applicant controls as in (1).

Importantly, we also include lender $\times$ year fixed effects to control for all observed and unobserved factors at the lender-year level. We also include market fixed effects to control for heterogeneity across local markets. This extensive set of controls allows us to control for all time-varying lender-specific shocks and demand-side factors associated with local market characteristics. Our identification thus comes from variations across loans in different loan segments and in different markets in the same lender and same year. This approach sharpens the identification and provides strong complementary evidence to the cross-lender tests we discussed earlier. Specifically, it allows us to test whether lenders behave differently when they expand to high-growth markets and to attribute the difference to lender behaviors in different markets.

Table $4 \mathrm{a}$ shows the results. The dependent variable is the average acceptance rate defined by the number of applications in columns 1 and 2 and by loan volume in columns 3 and 4 . We offer two main findings. First, lenders accept significantly fewer loan applications in peripheral markets than they do in primary markets. Such credit rationing is more pronounced for peripheral markets in high-growth areas. In other words, when lenders expand to high-growth markets, they ration credit significantly more than if they expand to nonhigh-growth markets. For example, column 1 (2) indicates that the average acceptance rate is 1 percentage point lower for peripheral markets in nonhigh-growth areas, compared to 2 (1.9) percentage points lower for peripheral markets in Sand States (constrained areas). This difference is also economically meaningful considering the average likelihood of the rejections of a loan is 12 percent. The results based on loan volume are very similar.

Second, lenders accept significantly fewer applications in the jumbo segment than they do in the conforming segment. The rationing of jumbo loans is more pronounced in high-growth areas. For example, column 1 suggests that the average acceptance rate (by the number of applications) for jumbo loans is 1.5 percentage points lower than conforming loans in non-Sand states. It is 2.8 percentage points lower than conforming loans in Sand States. As before, we interpret these two results of credit rationing as evidence of lenders investing less in private information to screen applicants in peripheral nonhigh-growth areas, and in jumbo segment in which loans are 
not eligible for GSE subsidies.

We have shown that lenders accept significantly fewer loan applications when they expand to high-growth markets. Is this driven by local or nonlocal lenders or both? To answer this question, we reestimate equation (3) by dropping market fixed effect. This allows us to estimate the average acceptance rate in high-growth markets relative to nonhigh-growth markets, which in turn allows us to estimate the change in acceptance rate when a nonlocal lender expands to a high-growth market. For a high-growth market lender, its change in acceptance rate when expanding to another high-growth market can be calculated from the coefficient of the primary market and its interaction with the high-growth market dummy.

We show the results in Table 4b. We find that when they expand to a high-growth market, both local and nonlocal lenders accept fewer applications. For example, column 4 shows that the difference for a nonlocal lender expanding to a constrained area is 1.6 percentage points (measured by loan volume) in the conforming segment and 4.3 percentage points in the jumbo segment (column 4). In comparison, the difference for a constrained-area lender expanding to another constrained area is 2.3 percentage points (measured by loan volume) in the conforming segment and 4.5 percentage points in the jumbo segment 9 The difference between the conforming and jumbo segment further corroborates our previous results involving a greater degree of credit rationing for jumbo loans. Overall, local and nonlocal lenders similarly reduce their acceptance rate when they expand to high-growth markets; therefore, the results we find in Table $4 \mathrm{a}$ are driven by both local and nonlocal lenders.

Thus far, we have defined local markets by 3-digit zip codes. As we discussed earlier, we do so because this measure aligns well with the administrative and economic boundaries of local housing markets. A reasonable alternative definition is counties that delineate the boundaries of local administrative regions and tend to be of similar size as 3-digit zip codes. MSAs are another commonly used definition in the literature. An MSA is usually defined by a county or counties with close economic ties. As a result, using the MSA allows one to treat an area larger than a county as a single local market. The disadvantage of MSA is that it does not include regions outside urban areas (above a population threshold), which may capture local housing market activities better than counties. For robustness checks, we reestimate our regression, using counties and MSAs as alternative definitions of local market

\footnotetext{
${ }^{9}$ The differences are obtained by the coefficients in column $4: 0.015-(-0.001)=0.016,0.015-(-$ $0.001)+0.022-(-0.005)=0.043,0.015+0.008=0.023$, and $0.015+0.022+0.008=0.045$.
} 
and we obtain very similar results (Appendix Tables A1 and A2) ${ }^{10}$

\section{EVIDENCE FROM LENDER PROFITABIL- ITY AND RISK}

We have shown that lenders expanding to high-growth markets accept fewer loan applications. Can the results be driven by lenders greater selectivity in these markets? If they are more selective in high-growth markets, they ought to perform better and have lower risk. If, in contrast, they invest less in private information for screening and risk assessment, they will not be able to price risks as accurately and thus perform more poorly and bear higher risk. Based on these arguments, we test how expansion to high-growth areas affect lender performance.

We estimate equation (2) with measures for lender profitability and risks as independent variables: return of equity (ROE), daily stock return volatility, and excess stock return volatility. ROE, measured as the ratio of net income to equity, captures lender profitability on and off the balance sheet because net income accounts for all interest and fees as well as loan loss provisions. Excess stock return is calculated as the difference between stock return and the 10-year treasury bond yield. As before, our key variables of interest are a lender's exposure to high-growth markets and interaction with the high-growth-market lender indicator. We include the same set of lender-level controls as in (1), and we include year fixed effects to control for aggregate shocks.

Table 5 reports the results. We find mixed evidence from lender profitability. Exposure to Sand States is not significantly associated with ROE for local or nonlocal lenders to Sand States (column 1). Exposure to constrained areas is negatively correlated with ROE for nonlocal lenders but positively associated with ROE for local lenders (column 2).

The evidence from lender risk is strong and robust. Exposure to high-growth markets is positively correlated with volatility for nonlocal lenders (columns 3 to 6 ). The effect is statistically significant and economically large. A 1 standard deviation increase (28.4 percent) in exposure to Sand States is associated with a 0.67 increase

\footnotetext{
${ }^{10}$ We define constrained areas as counties (MSAs) at the bottom decile of the Lutz and Sand (2019) (Saiz 2010) index.
} 
in stock return volatility (column 3). For constrained areas, a 1 standard deviation increase (19 percent) in exposure is associated with a 0.43 increase in stock return volatility (column 4). Results of excess return volatility are quantitatively very similar (column 5 and 6). In contrast, we find a negligible effect of high-growth market exposure on the risks of local-lenders. The interaction term of high-growth market exposure and local-lender dummy is negative with a magnitude that offsets the stand-alone term of high-growth market exposure (with a positive sign). As a result, the overall effect is not statistically different from zero. Consistent with Table 3, this finding on the difference between local and nonlocal lenders also suggests that the effect of high-growth market exposure is unique to nonlocal lenders expanding to high-growth markets.

The mixed results on profitability, together with the robust results on risks, may reflect a subtle tradeoff between lenders' risk and return - a point to which we will return in the next section.

We further evaluate lenders' systemic risk (SRISK), which captures the externality of lender distress in relation to the rest of the financial system or the real economy. We follow Brownlees and Engle (2017) and Acharya et al. (2012) to proxy systemic risk through an SRISK measure, defined as a lender's contribution to the deterioration of the capitalization of the financial system as a whole during a crisis. SRISK is calculated in two steps. The first step estimates marginal expected shortfall (MES), defined as the tail expectation of a firm's equity return conditional on a market decline. The second step calculates the firm's expected capital shortfall given its capitalization and the MES 11 The calculation of SRISK results in a significant loss of our sample because it is limited to large lenders trading on the stock exchange. We are left with a sample of 67 lenders over a sample period of 2000-2017.

Table 6 shows the results. We find that exposure to Sand States is associated with higher MES for nonlocal lenders and lower MES for local lenders in these markets (column 1). Results of exposure to constrained areas is similar, and they are statistically significant for SRISK (column 4) but not for MES (2). Effects of exposure to Sand States on SRISK is also not statistically significant (column 3). Overall, evidence of systemic risk seems inconclusive. We note that the small sample size in these analyses means that results in systemic risk may not be representative of all lenders and may not be comparable to our earlier results.

\footnotetext{
${ }^{11}$ We follow Brownlees and Engle (2017) and calculate SRISK as the percentage of capital shortfall when the U.S. financial stock index falls by 40 percent over six months.
} 
To sum up evidence from lender profitability and risk, we find that exposure to high- growth markets is associated with higher stock return volatility for nonlocal lenders in these markets. These results provide direct evidence of the linkage between mortgage exposure and lender risk. They also corroborate results in Section II indicating that credit rationing in high-growth markets is likely the result of a lower level of screening rather than more selective lenders.

\section{EVIDENCE FROM PORTFOLIO RISK}

Our early results hinted at a subtle tradeoff of lenders' risk and return. In this section, we further explore this tradeoff by examining evidence from lenders' mortgage portfolios. Unlike our early analyses of equity-based measures of risk, which may reflect a lender's business unrelated to mortgage lending, the analysis in this section is based solely on lenders' mortgage portfolio composition. Our analysis proceeds in three steps. We first construct all lenders' mortgage portfolios in our sample. We then evaluate their portfolio volatilities. Finally, we assume an asset pricing model and use it to conduct a mean-variance analysis at the lender level.

\subsection{Portfolio Risk}

We construct a lender's mortgage portfolios each year based on loans kept on the lender's books ${ }^{12}$ Because we are interested in the geographic distribution of the loans, we treat loans in the same local market as a single asset in the portfolio. This approach abstracts from the heterogeneity of loans within a local market and allows us to focus on portfolio composition across markets. This approach also provides a good approximation of key risks associated with lenders' mortgage exposure because the credit risks of loans in a local market are idiosyncratic and more diversifiable than the risks across markets correlated with housing markets (Cotter et al. 2015).

Because we observe no trading of assets during the period, we cannot directly compute asset return. We instead estimate the moment of asset return. Assume

\footnotetext{
${ }^{12}$ After origination, lenders may sell or securitize the loans or keep them on the books. HMDA does not provide direct information on whether a loan is sold or securitized, but we can see whether the loan remains on the book. The vast majority of loan sale and securitization occurs shortly after loan origination with the likelihood of loan sale and securitization drops significantly after 120 days (Jiang et al. 2014).
} 
each asset generates a random return between the end of period $t$ and period $t+1$. For a portfolio with $N$ assets, we compute the variance-covariance matrix of the assets $\Sigma$. We proxy quarterly return in a local market by its quarterly house price growth plus the average mortgage rate.

Housing price growth is a good proxy for our purpose for several reasons. The return of a mortgage portfolio depends on interest income and expected loss. Mortgage loans are more profitable when house prices increase (Chakraborty et al. 2018). The expected loss of the mortgage portfolio is lower when house prices increase because the loans are less likely to default (Deng et al. 2000; Ghent and Kudlyak 2011; Bajari et al. 2013) and loss given default is also lower (Qi and Yang, 2009; Andersson and Mayock, 2014; Park and Bang, 2014) 13 Finally, what matters in practice for lenders' risk-return tradeoff is the lender's information set about the future return of the market. House price is a key indicator that lenders use to assess the credit risk of local markets 14

\subsection{Estimating the mean returns of portfolios}

As acknowledged in the literature, expected asset returns are difficult to estimate especially if the sample period is short; therefore, we opt to infer the mean portfolio return from an asset pricing model. Even if the asset pricing model is not exactly correct, it likely gives us better estimates than the direct approach because it reduces the variance of the estimate (Calvet et al. 2007).

The capital asset pricing model (CAPM) is a natural framework for our purpose because it captures expected excess return associated with portfolio diversification. We assume that lenders can trade risk-free assets in the market. Thus, the CAPM holds in mortgage portfolio excess returns relative to U.S. Treasury bills:

$$
r_{j t}^{e}=\beta_{j} r_{m t}^{e}+\epsilon_{j t}
$$

where the market return $r_{m t}^{e}$ is measured as the excess return of a market portfolio of mortgages. The market portfolio aggregates all geographic markets in the US, weighted by total loan volumes. Intuitively, the market portfolio is constructed as

\footnotetext{
${ }^{13}$ Hurst et al. (2016) show that conditional on mortgage characteristics, mortgage rates do not vary geographically despite significant variations in default risks related to local house prices, suggesting that local default risk is a key factor in local mortgage return.

${ }^{14}$ Indicators for aggregate conditions are less relevant for our purpose because, as we will show, we are assessing individual lenders' portfolios relative to the national portfolio.
} 
if a lender holds a representative "national portfolio," which reflects the extent to which a lender can diversify in the country. Specifically,

$$
r_{m t}^{e}=R_{m t}+r_{t}-r_{t}^{f}
$$

where $R_{m t}$ captures return from house price appreciation, calculated as the valueweighted house price growth in all the geographic markets in the US in year $t$. $r_{t}$ captures return from interest payment, measured by the average mortgage rate in year $t t^{15}$ The excess return of a lender's portfolio $r_{j t}^{e}$ is calculated similarly as $r_{j t}^{e}=R_{j t}+r_{t}-r_{t}^{f}$, where $R_{j t}$ is the value-weighted house price growth in all the markets in which lender $j$ has presence in year $t$. Using equation (5), we estimate portfolio mean return $\mu$ given the variance-covariance matrix $\Sigma$, following standard procedure summarized in Calvet et al. (2007). Figure 5 illustrates mortgage portfolios in the mean-standard deviation plane for all lenders in 2017. The national portfolio, denoted by a black diamond, appears quite efficient.

Table 7 summarizes portfolio risks across lenders. The average mortgage portfolio return is 5.93 percent with a standard deviation of 3.58 percent. Average risk is about 5.76 percent.

\subsection{Mean-variance analysis of mortgage portfolios}

We now proceed with a quantitative assessment of portfolio risk and return using moments computed with equation (5). For each lender i's portfolio in each year, we denote the mean and standard deviation of the excess of return by $\mu_{i}$ and $\sigma_{i}$. The corresponding Sharpe ratio is $S_{i}=\mu_{i} / \sigma_{i}$. We similarly define the Sharpe ratio of a benchmark (i.e. national) portfolio as $S_{B}=\mu_{B} / \sigma_{B}$.

Portfolio risk, return, and efficiency can be accessed against the benchmark portfolio in the following way:

$$
\sigma_{i}=\frac{R L_{i}}{S_{B} R S R L_{i}}
$$

where $R S R L_{i}$ is the relative Sharpe ratio loss defined as $1-S_{i} / S_{B} . R L_{i}$ is the average return loss by choosing portfolio $i$ instead of a position combining the benchmark portfolio with cash to achieve the same risk level: $R L_{i}=S_{B} \sigma_{i}-\mu_{i}{ }^{16}$ Thus, portfolio

\footnotetext{
${ }^{15}$ Ideally, we would use the mortgage rate for each geographic market and each year, but data for this level of disaggregation are not available.

${ }^{16}$ When the benchmark is mean-variance efficient, return loss measures the vertical distance between portfolio i and the efficient frontier.
} 
volatility is related to return (measured by RL) and portfolio inefficiency (measured by relative Sharpe ratio loss). Taking logs of (6) gives

$$
\ln \sigma_{i}=\ln R L_{i}-\ln R S R L_{i}-\gamma
$$

where $\gamma=\ln S_{B}$ is a constant. This equation can be intuitively interpreted: higher portfolio risk $\left(\ln \sigma_{i}\right)$ can be compensated by higher return (i.e. lower return loss $\left.\ln R L_{i}\right)$, and the uncompensated risk results in lower portfolio efficiency $\left(\ln R S R L_{i}\right)$.

To assess how exposure to high-growth market affects the lender's mortgage portfolio risk, return, and efficiency, we regress each components of equation (7) on the same set of covariates as in equation (2). As we noted earlier, the results on portfolio risk does not rely on any asset price model while the results on return and efficiency do.

Table 8 reports the results. We have three main findings. First, consistent with our earlier results on stock return volatility, we find that exposure to high-growth markets is significantly positively associated with portfolio risk for nonlocal lenders (columns 1 and 2). For example, a 1 standard deviation increase in exposure is associated with a $0.26(0.11)$ increase in the log of portfolio risk for nonlocal lenders in Sand States (constrained areas). The interaction term of high-growth market exposure and local lender dummy is negatively significant, indicating a significantly smaller effect for local lenders. In the case of constrained areas (column 2), the magnitude of the interaction term offsets the standalone term for exposure, suggesting a negligible effect of exposure to constrained areas on local lenders. In the case of Sand States, the interaction term is negatively significant with a smaller magnitude than the standalone term; therefore, the overall result remains positive for local lenders albeit with a much smaller magnitude than nonlocal lenders.

Second, exposure to high-growth markets is associated with lower return loss (i.e., higher return) for nonlocal lenders (columns 3 and 4). A 1 standard deviation increase in the lending share to Sand States (constrained areas) is associated with 1.1 (0.2) decrease in the log of return loss for nonlocal lenders. For local lenders, the effect is negligible.

Third, exposure to high-growth markets is negatively associated with relative Sharpe ratio loss for nonlocal lenders (columns 5 and 6), whereas the effect for local lenders is again negligible. 
Exposure to high-growth markets has significant implications for portfolio performance: it increases portfolio risk yet improves portfolio efficiency and return. Similar to previous results based on stock market volatility, results of portfolio risks are consistent with the notion that nonlocal lenders in high-growth areas make lessinformed investments. Together with results of portfolio efficiency and return, our results point to subtle portfolio tradeoff. The high risk associated with less-informed investment by nonlocal lenders in high growth markets may reflect lenders' portfolio strategy: They may be willing to accept higher risk in exchange for higher portfolio efficiency and higher return.

\section{DISCUSSION AND CONCLUDING REMARKS}

A few years after the 2007-2008 crisis, U.S. housing markets rebounded. The national average housing price grew by 2.6 percent between 2010 and 2017. Perhaps unsurprisingly, high-growth areas again grow faster than other parts of the country. Housing prices in Sand States have soared from the postcrisis trough, reaching nearly the precrisis peak by 2017. Constrained areas follow a similar trend albeit at a smaller magnitude. Since the trough in 2010, the share of lending to Sand States has grown at a faster rate than during the runup to the crisis and surpassed the precrisis peak by 2016. We cannot help but wonder whether this boom differs from the previous one?

In the Appendix (Tables A3-A8), we show that all our findings continue to hold in the postcrisis period. Nonlocal lenders in high-growth markets continue to ration credit more in these areas, significantly more so in the jumbo segment than in the conforming segment. Their stock return volatility continues to increase with exposure to high-growth markets. Their portfolio tradeoff involving higher risk, high efficiency, and high return associated with high-growth markets also continues to hold. Although the housing market may have seen many changes since the last crisis, these results warn against ill-informed investment and associated risk in high-growth areas during a new housing boom. 


\section{References}

[1] Acharya, Viral V., Iftekhar Hasan and Anthony Saunders. Should banks be diversified? Evidence from individual bank loan portfolios. Journal of Business 79, 1355-1412, 2006.

[2] Acharya, Viral V., Lasse H. Pedersen, Thomas Philippon, and Matthew Richardson. Measuring systemic risk. Review of Financial Studies 30, 2-47, 2017.

[3] Altunbasa, Yener, Simone Manganellib, and David Marques-Ibanez. Realized bank risk during the great recession. Journal of Financial Intermediation 32, 29-44, 2017.

[4] Andersson, Fredrik and Tom Mayock. Loss severities on residential real estate debt during the great recession. Journal of Banking and Finance 46, 266-284, 2014.

[5] Bajari, Patrick, Chenghuan Sean Chu and Minjung Park An empirical model of subprime mortgage default from 2000 to 2007. NBER working paper No. 14625, 2013.

[6] Berger, Allen N., Nathan H. Miller, Mitchell A. Petersen, Raghuram G. Rajan, and Jeremy C. Stein. Does function follow form? Evidence from the lending practices of large and small banks. Journal of Financial Economics 76, 237-69, 2005.

[7] Brownlees, Christian, and Robert F. Engle. SRISK: A conditional capital shortfall measure of systemic risk. Review of Financial Studies 30, 48-79, 2017.

[8] Calomiris, Charles W. and Sophia Chen. The spread of deposit insurance and the global rise in bank asset risk since the 1970s. Journal of Financial Intermediation, 2020 .

[9] Chakraborty, Indraneel, Itay Goldstein, and Andrew MacKinlay. Housing price booms and crowding-out effects in bank lending. Review of Financial Studies 31, 2806-2853, 2018.

[10] Cotter, John, Stuart Gabriel, and Richard Roll. Can housing risk be diversified?

A cautionary tale from the housing boom and bust. Review of Financial Studies 28, 913-936, 2015. 
[11] Dell'Ariccia, Giovanni, Deniz Igan, and Luc Laeven. Credit booms and lending standards: Evidence from the subprime mortgage market. Journal of Money, Credit, and Banking 44, 367-384, 2012.

[12] Deng, Yongheng, John M Quigley, and Robert Van Order. Mortgage terminations, heterogeneity and the exercise of mortgage options. Econometrica 68, 275-307, 2000.

[13] Hurst, Erik, Benjamin Keys, Amit Seru, and Joseph Vavra. Regional redistribution through the US mortgage market. American Economic Review 106, 2982-3028, 2016.

[14] FDIC. The sand states: Anatomy of a perfect housing-market storm. FDIC Quarterly 3, 30-32, 2009.

[15] Ghent, Andra and Marianna Kudlyak. Recourse and residential mortgagedefault: Evidence from US states. Review of Financial Studies, 24, 3139-3186, 2011.

[16] Goetz, Martin, Luc Laeven, and Ross Levine. Does the geographic expansion of banks reduce risk? Journal of Financial Economics 120, 346-362, 2016.

[17] Jiang, Wei, Ashlyn Aiko Nelson, and Edward,Vytlacil. Securitization and loan performance. Review of Financial Studies 27, 454-483, 2014.

[18] Keys, Benjamin J., Tanmoy Mukherjee, Amit Seru, Vikrant Vig. Did securitization lead to lax screening? Evidence from subprime loans. Quarterly Journal of economics 125, 307-362, 2010.

[19] Loutskina, Elena, and Philip E. Strahan. Informed and uninformed investment in housing: The downside of diversification. Review of Financial Studies 24, 1447-1480, 2011.

[20] Lutz, Chandler, and Ben Sand. Highly disaggregated topological land unavailability. Working paper, 2019.

[21] Mian, Atif R., Amir Sufi. The consequences of mortgage credit expansion: Evidence from the U.S. mortgage default crisis. Quarterly Journal of economics 124, 1449-1496, 2009.

[22] Mian, Atif R., Amir Sufi. House prices, home equity-based borrowing, and the US household leverage crisis. American Economic Review 101, 2132-2156, 2011. 
[23] Mian, Atif R., Kamalesh Rao, Amir Sufi. Household balance sheets, consumption, and the economic slump. Quarterly Journal of economics 128, 1687-1726, 2013.

[24] Mian, Atif R., Amir Sufi, Emil Verner. Household debt and business cycles worldwide. Quarterly Journal of Economics 132, 1755-1817, 2017.

[25] Park, Yun and Doo Won Bang. Loss given default of residential mortgages in a low LTV regime: Role of foreclosure auction process and housing market cycles. Journal of Banking and Finance 46, 192-210, 2014.

[26] Qi, Min and Xiaolong Yang. Loss given default of high loan-to-value residential mortgages. Journal of Banking and Finance 33, 788-799, 2009.

[27] Saiz, Albert. The geographic determinants of housing supply. Quarterly Journal of Economics 125, 1253-1296, 2010. 


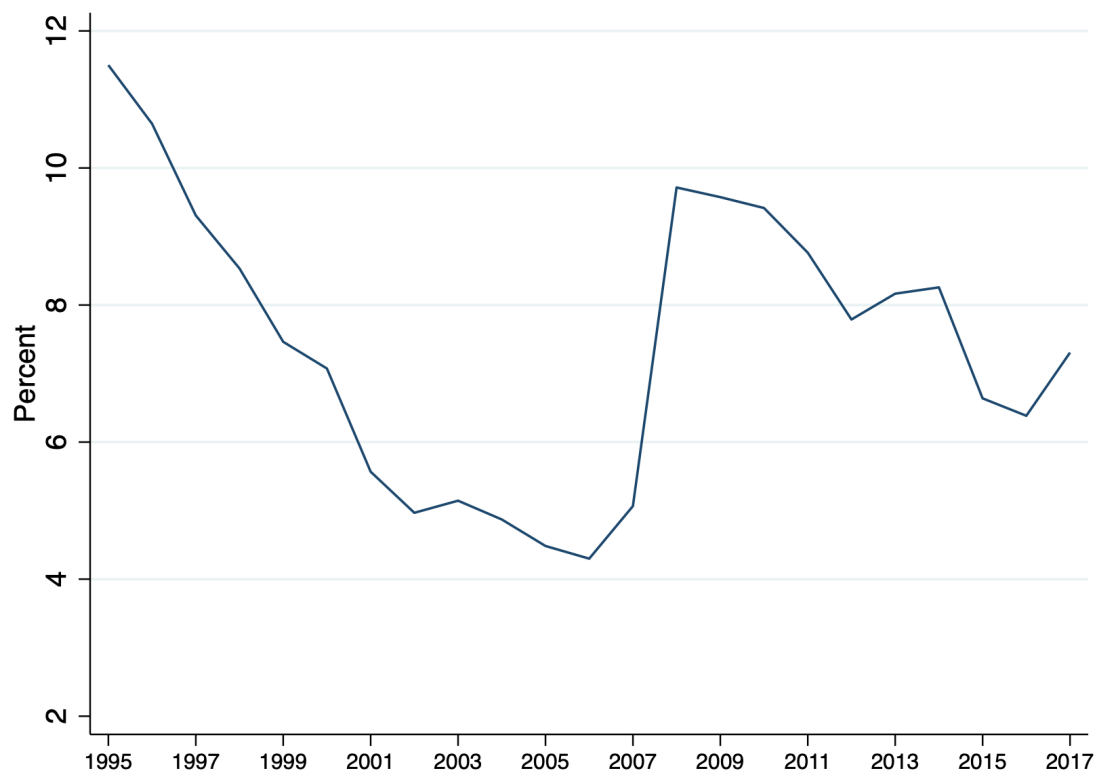

Figure 1: Mortgage origination by Local Lenders.

This figure plots the share of mortgage origination by local lenders. Local lender is defined as those with 50 percent or more of total lending in a single local market. 


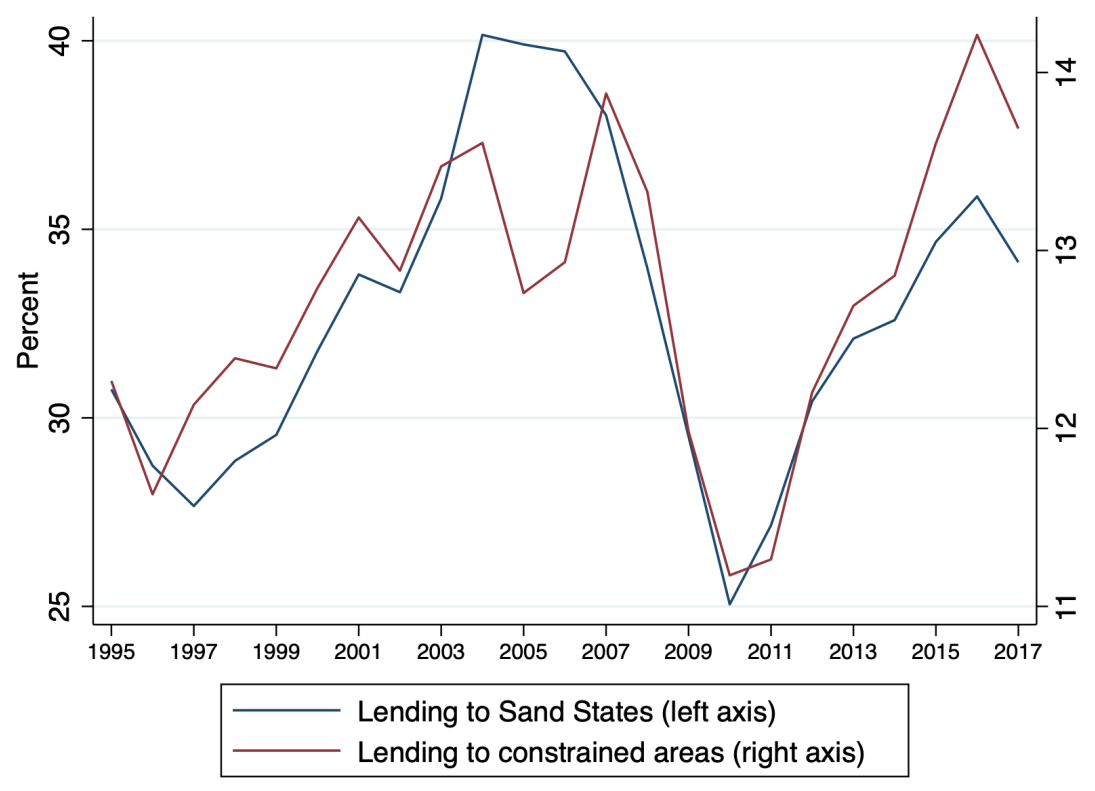

Figure 2: Mortgage Lending in High-Growth Markets.

This figure plots the share of mortgage lending in high-growth markets. High-growth markets are measured by Sand States (Arizona, California, Florida, and Nevada) or constrained areas, defined as areas with land availability in the bottom decile according to Lutz and Sand (2019). 


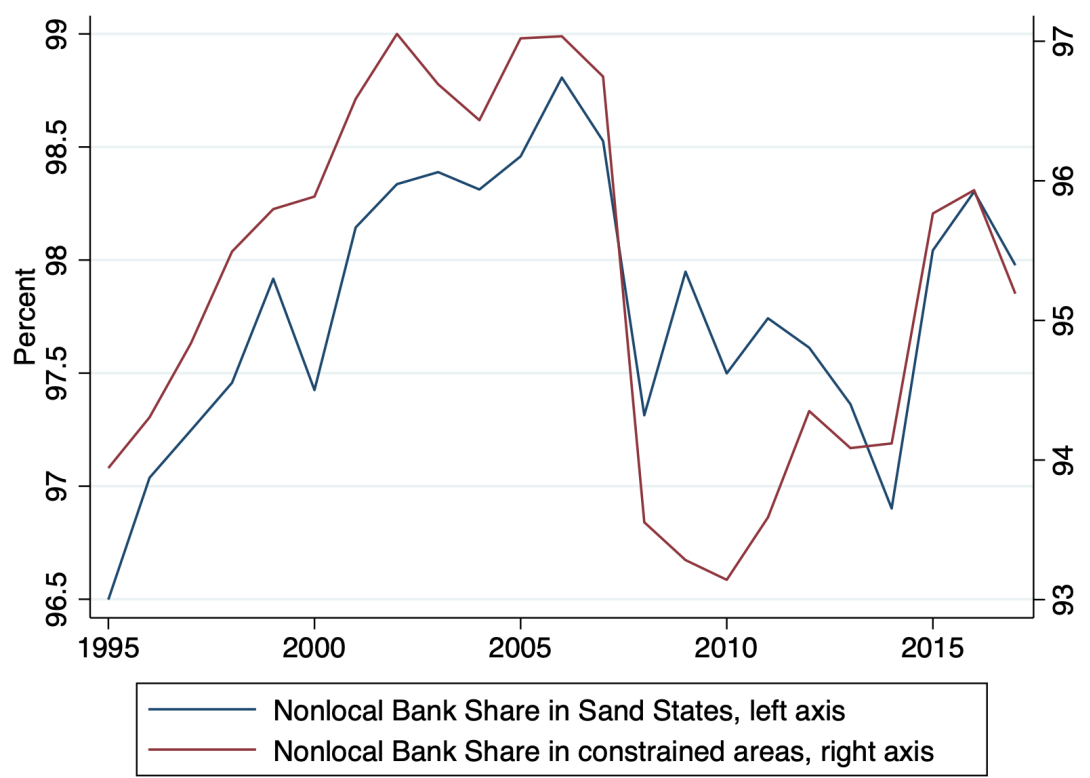

Figure 3: Nonlocal Lender Share in High-Growth Markets.

This figure plots the share of mortgage lending by nonlocal lenders in high-growth markets. Nonlocal lender is defined as those with less than 50 percent of total lending in a single local market. High-growth markets are measured by Sand States (Arizona, California, Florida, and Nevada) or constrained areas, defined as areas with land availability in the bottom decile according to Lutz and Sand (2019). 


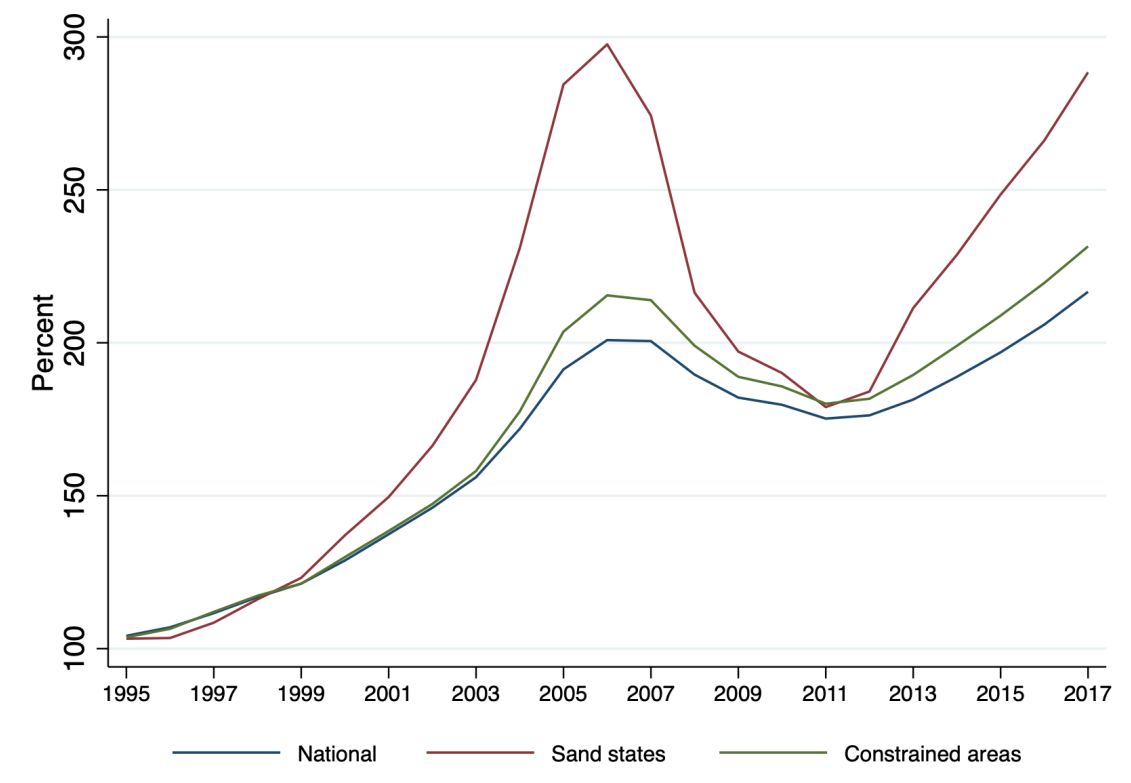

Figure 4: House Price Index in High-Growth Markets.

This figure plots the average house prices in the U.S. and in high-growth markets. High-growth markets are measured by Sand States (Arizona, California, Florida, and Nevada) or constrained areas, defined as areas with land availability in the bottom decile according to Lutz and Sand (2019). House price data is from Federal Housing Finance Agency. House prices in 1994 is normalized to 100. 


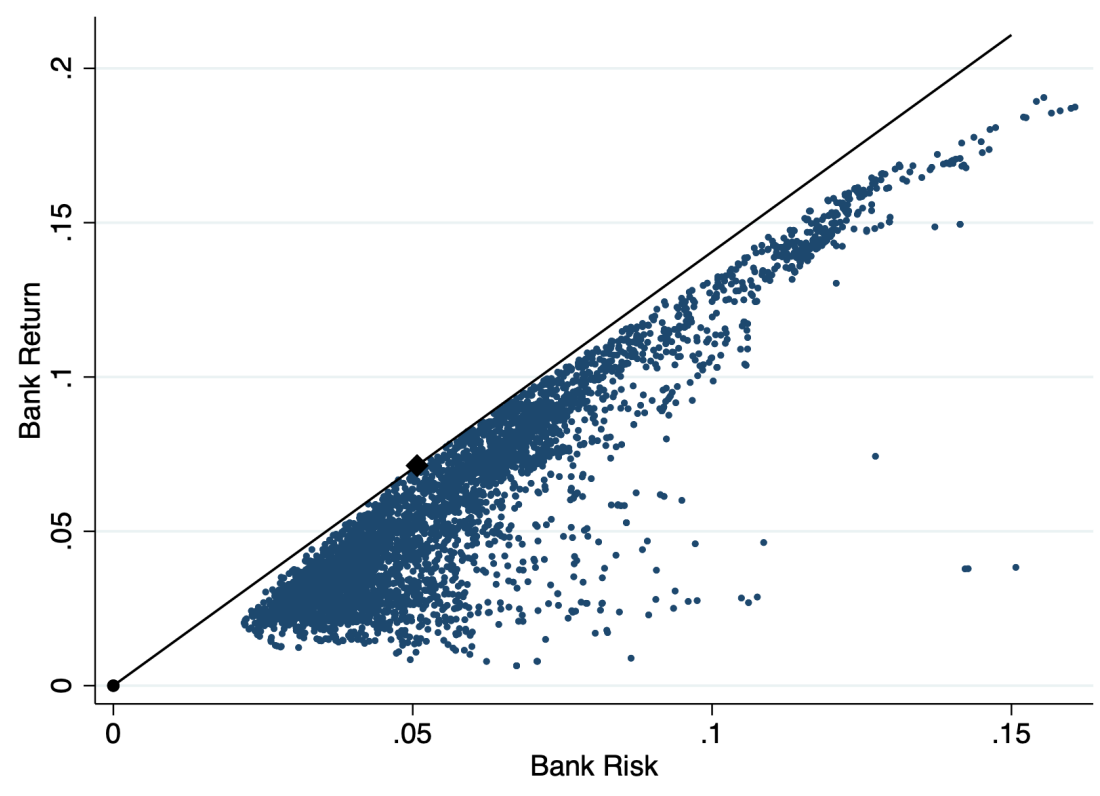

Figure 5: Mortgage Portfolio Return and Risk.

This figure plots lender-level mortgage portfolio return and risk in 2017 estimated with CAPM. The national portfolio is denoted by a black diamond. 


\section{Table 1: Summary Statistics of Mortgage Acceptance Rate}

Notes: This table provides summary statistics for acceptance rate (conforming loans in Panel A and jumbo loans in Panel B) and lender characteristics (Panel C). Acceptance rates are calculated as the number (volume) of accepted applications divided by the total number (Volume) of applications. Total assets, tier 1 capital ratio, and deposit to asset ratio and return on equity, are from Call Report. Diversification and share of lending to high-growth markets are computed from HMDA data. Diversification is measured as 1 minus the sum of squared shares of mortgages in all markets in which the lender operates, and it ranges from zero (for lenders that lend to a single market) to nearly 1 (for lenders that operate in many markets). High-growth markets are measured by Sand States (Arizona, California, Florida, and Nevada) or constrained areas, defined as areas with land availability in the bottom decile according to Lutz and Sand (2019).

\begin{tabular}{lcccccc}
\hline & $(1)$ & $(2)$ & $(3)$ & $(4)$ & $(5)$ & $(6)$ \\
Variables & $\mathrm{N}$ & Mean & Std & $\mathrm{p} 10$ & $\mathrm{p} 50$ & $\mathrm{p} 90$ \\
\hline Panel A: Conforming Loans & & & & & & \\
No. of accepted application & 83088 & 1448 & 20964 & 11 & 106 & 830 \\
No. of rejected application & 83088 & 487 & 9323 & 0 & 13 & 113 \\
No. of unsecuritized loans & 83088 & 637 & 8905 & 8 & 74 & 437 \\
Vol. of accepted application (million) & 83088 & 190 & 3206 & .974 & 9.08 & 96.7 \\
Vol. of rejected application (million) & 83088 & 48.9 & 1056 & 0 & .947 & 10.8 \\
Vol. of unsecuritized loans (million) & 83088 & 65.6 & 1096 & .751 & 5.97 & 39.3 \\
Ave. size of accepted application (thousand) & 82477 & 110 & 65.8 & 43.1 & 96.2 & 191 \\
Ave. size of unsecuritized loans (thousand) & 81616 & 100 & 65.5 & 39.7 & 84.4 & 180 \\
Average income (thousand) & 81699 & .117 & .131 & .0503 & .0924 & .193 \\
Pct. of full documentation & 82625 & .837 & .214 & .548 & .921 & 1 \\
Pct. of women & 82031 & .209 & .156 & .0366 & .183 & .406 \\
Pct. of minority & 81940 & .0362 & .103 & 0 & .0017 & .0952 \\
Acceptance rate by number & 82625 & .87 & .12 & .73 & .896 & .998 \\
Acceptance rate by volume & 82625 & .882 & .123 & .742 & .913 & 1 \\
& & & & & & \\
Panel B: Jumbo Loans & & & & & & \\
No. of accepted application & 83088 & 114 & 2299 & 0 & 3 & 37 \\
No. of rejected application & 83088 & 23.8 & 560 & 0 & 0 & 4 \\
No. of unsecuritized loans & 83088 & 83.1 & 1765 & 0 & 3 & 29 \\
Vol. of accepted application (million) & 83088 & 79.4 & 1421 & 0 & 2.1 & 30.7 \\
Vol. of rejected application (million) & 83088 & 16.3 & 357 & 0 & 0 & 3.05 \\
Vol. of unsecuritized loans (million) & 83088 & 61.1 & 1159 & 0 & 1.76 & 25.5 \\
Ave. size of accepted application (thousand) & 65503 & 790 & 1469 & 319 & 621 & 1288 \\
Ave. size of unsecuritized loans (thousand) & 63593 & 805 & 1488 & 322 & 636 & 1320 \\
Average income (thousand) & 60256 & .353 & .428 & .107 & .249 & .646 \\
Pct. of full documentation & 66806 & .641 & .353 & 0 & .733 & 1 \\
Pct. of women & 62135 & .096 & .19 & 0 & 0 & .304 \\
Pct. of minority & 61935 & .0209 & .101 & 0 & 0 & .0236 \\
Acceptance rate by number & 66806 & .903 & .186 & .696 & 1 & 1 \\
Acceptance rate by volume & 66806 & .904 & .192 & .696 & 1 & 1 \\
\hline & & & & & & \\
\hline
\end{tabular}




\begin{tabular}{lcccccc}
\hline & $(1)$ & $(2)$ & $(3)$ & $(4)$ & $(5)$ & $(6)$ \\
Variables & $\mathrm{N}$ & Mean & Std & $\mathrm{p} 10$ & $\mathrm{p} 50$ & $\mathrm{p} 90$ \\
\hline Panel C: Lender Characteristics & & & & & & \\
Total assets (millions) & 83088 & 2394 & 34210 & 58.9 & 206 & 1235 \\
Tier 1 ratio & 79139 & .15 & .0777 & .0961 & .131 & .222 \\
Deposit/Total assets & 83088 & .833 & .0787 & .739 & .85 & .906 \\
Return on equity & 83088 & .764 & 1.11 & .0524 & .878 & 1.59 \\
Diversification & 82929 & .554 & .249 & .157 & .598 & .845 \\
Share of lending in sand states & 82929 & .101 & .284 & 0 & 0 & .338 \\
Share of lending in constrained areas & 82929 & .0616 & .192 & 0 & 0 & .142 \\
\hline
\end{tabular}




\section{Table 2: Acceptance Rate and Exposure to High-growth Markets}

Notes: This table shows results on the relationship between acceptance rate and exposure to high-growth markets at the lender level over the period of 1995-2017. Panel A (B) reports the results for conforming loans (jumbo loans). Acceptance rates are calculated as the number of accepted applications divided by the total number of applications. High-growth markets are measured by Sand States (Arizona, California, Florida, and Nevada) or constrained areas, defined as areas with land availability in the bottom decile according to Lutz and Sand (2019). Applicant controls include the share of loans with full documentation, the share of women applicants, and share of minority applicants. Lender controls include the log of total assets, Tier 1 capital ratio, and deposit to asset ratio. We also include year fixed effects. Standard errors clustered at the lender level are in parentheses. ${ }^{* *},{ }^{* *}$, and ${ }^{*}$ indicate statistical significance at the 1,5 , and 10 percent level, respectively.

$(1)$

$(2)$

$(3)$

$(4)$

\section{Panel A: Conforming Loans}

Exposure to High-Growth Markets (sand states)

Exposure to High-Growth Markets (constrained areas)

Applicant controls

Lender controls

Year FE

$\mathrm{N}$

$R^{2}$

$\begin{array}{cc}-0.044^{* * *} & \\ (0.005) & -0.021^{* * *} \\ & (0.006) \\ & \text { No } \\ \text { No } & \text { Yes } \\ \text { Yes } & \text { Yes } \\ \text { Yes } & 69,580 \\ 69,580 & 0.029 \\ 0.038 & \end{array}$

$-0.051^{* * *}$

$(0.005)$

$\begin{array}{cc} & -0.024^{* * *} \\ & (0.006) \\ \text { Yes } & \text { Yes } \\ \text { Yes } & \text { Yes } \\ \text { Yes } & \text { Yes } \\ 68,723 & 68,723 \\ 0.088 & 0.076\end{array}$

Panel B: Jumbo Loans

Exposure to High-Growth Markets (sand states)

$-0.052^{* * *}$

$(0.005)$

Exposure to High-Growth Markets (constrained areas)

Applicant controls

Lender controls

Year FE

$\mathrm{N}$

$R^{2}$

No
Yes
Yes
57,426
0.023

$-0.056^{* * *}$

$(0.005)$

$-0.032^{* * *}$

(0.006)

No

Yes

Yes

57,426

0.018
$-0.034^{* * *}$

(0.006)

Yes

Yes

Yes

51,103

0.038 


\section{Table 3a: Acceptance Rate of Local and Nonlocal Lenders, Conforming Loans}

Notes: This table shows results on the relationship between acceptance rate of conforming loans and exposure to high-growth markets over the period of 1995-2017. Acceptance rates are calculated as the number of accepted applications divided by the total number of applications. Local lender in high-growth markets is defined as those with 25 percent or more of total lending in those markets. High-growth markets are measured by Sand States (Arizona, California, Florida, and Nevada) or constrained areas, defined as areas with land availability in the bottom decile according to Lutz and Sand (2019). Applicant controls include the share of loans with full documentation, the share of women applicants, and share of minority applicants. Lender controls include the log of total assets, Tier 1 capital ratio, and deposit to asset ratio. We also include year fixed effects.

Standard errors clustered at the lender level are in parentheses. ${ }^{* *},{ }^{* *}$, and ${ }^{*}$ indicate statistical significance at the 1,5 , and 10 percent level, respectively.

\begin{tabular}{lcccc}
\hline & $(1)$ & $(2)$ & $(3)$ & $(4)$ \\
\hline Measure using sand states: & & & & \\
Exposure to High-Growth Markets & $-0.129^{* * *}$ & & $-0.126^{* * *}$ & \\
& $(0.040)$ & & $(0.038)$ & \\
Local Lender & $-0.037^{* *}$ & & $-0.030^{* *}$ & \\
& $(0.015)$ & & $(0.014)$ & \\
Exposure to HGM * Local Lender & $0.122^{* * *}$ & & $0.104^{* *}$ & \\
& $(0.046)$ & & $(0.043)$ & \\
Measure using constrained areas: & & $-0.197^{* * *}$ & & $-0.210^{* * *}$ \\
Exposure to High-Growth Markets & & $(0.032)$ & & $(0.031)$ \\
& & $-0.019^{* *}$ & & $-0.019^{* *}$ \\
Local Lender & & $(0.009)$ & & $(0.009)$ \\
& & $0.203^{* * *}$ & & $0.214^{* * *}$ \\
Exposure to HGM * Local Lender & & $(0.036)$ & & $(0.035)$ \\
& No & No & Yes & Yes \\
Applicant controls & Yes & Yes & Yes & Yes \\
Lender controls & Yes & Yes & Yes & Yes \\
Year FE & 73,285 & 73,285 & 72,403 & 72,403 \\
\hline $\mathrm{N}$ & 0.037 & 0.029 & 0.087 & 0.077 \\
$R^{2}$ & & & &
\end{tabular}




\section{Table 3b: Acceptance Rate of Local and Nonlocal Lenders, Jumbo Loans}

Notes: This table shows results on the relationship between acceptance rate of jumbo loans and exposure to high-growth markets over the period of 1995-2017. Acceptance rates are calculated as the number of accepted applications divided by the total number of applications. Local lender in high-growth markets is defined as those with 25 percent or more of total lending in those markets. High-growth markets are measured by Sand States (Arizona, California, Florida, and Nevada) or constrained areas, defined as areas with land availability in the bottom decile according to Lutz and Sand (2019). Applicant controls include the share of loans with full documentation, the share of women applicants, and share of minority applicants. Lender controls include the log of total assets, Tier 1 capital ratio, and deposit to asset ratio. We also include year fixed effects.

Standard errors clustered at the lender level are in parentheses. ${ }^{* *},{ }^{* *}$, and ${ }^{*}$ indicate statistical significance at the 1,5 , and 10 percent level, respectively.

\begin{tabular}{|c|c|c|c|c|}
\hline & (1) & $(2)$ & (3) & (4) \\
\hline \multicolumn{5}{|l|}{ Measure using sand states: } \\
\hline Exposure to High-Growth Markets & $\begin{array}{c}-0.237^{* * *} \\
(0.051)\end{array}$ & & $\begin{array}{c}-0.267^{* * *} \\
(0.051)\end{array}$ & \\
\hline Local Lender & $\begin{array}{c}-0.066^{* * *} \\
(0.016)\end{array}$ & & $\begin{array}{c}-0.072^{* * *} \\
(0.016)\end{array}$ & \\
\hline Exposure to HGM * Local Lender & $\begin{array}{c}0.251^{* * *} \\
(0.058)\end{array}$ & & $\begin{array}{c}0.285^{* * *} \\
(0.059)\end{array}$ & \\
\hline \multicolumn{5}{|l|}{ Measure using constrained areas: } \\
\hline Exposure to High-Growth Markets & & $\begin{array}{c}-0.247^{* * *} \\
(0.036)\end{array}$ & & $\begin{array}{c}-0.275^{* * *} \\
(0.037)\end{array}$ \\
\hline Local Lender & & $\begin{array}{c}-0.035^{* * *} \\
(0.011)\end{array}$ & & $\begin{array}{c}-0.034^{* * * *} \\
(0.011)\end{array}$ \\
\hline Exposure to HGM * Local Lender & & $\begin{array}{c}0.264^{* * *} \\
(0.040)\end{array}$ & & $\begin{array}{c}0.289^{* * *} \\
(0.042)\end{array}$ \\
\hline Applicant controls & No & No & Yes & Yes \\
\hline Lender controls & Yes & Yes & Yes & Yes \\
\hline Year FE & Yes & Yes & Yes & Yes \\
\hline $\mathrm{N}$ & 60,113 & 60,113 & 53,646 & 53,646 \\
\hline$R^{2}$ & 0.024 & 0.019 & 0.045 & 0.039 \\
\hline
\end{tabular}




\section{Table 4a: Acceptance Rate: Within-Lender Test}

Notes: This table shows within-lender test for the acceptance rate at lender-market-year level over the period of 1995-2017. Acceptance rates are calculated based on loan number in columns 1-2, and loan volume in columns 3-4. Primary market is dummy that takes the value 1 for the market with the largest share of a lender in a year. Jumbo is a dummy that takes the value 1 for the jumbo segment. Local lender is a dummy that takes the value 1 for lenders with 25 percent or more of total lending in high-growth markets. High-growth markets are measured by Sand States (Arizona, California, Florida, and Nevada) or constrained areas, defined as areas with land availability in the bottom decile according to Lutz and Sand (2019). Applicant controls include the share of loans with full documentation, the share of women applicants, and share of minority applicants. Lender controls include the log of total assets, Tier 1 capital ratio, and deposit to asset ratio. We also include market fixed effects and lender $\times$ year fixed effects. Standard errors clustered at the lender-year level are in parentheses. ${ }^{* * *},{ }^{* *}$, and ${ }^{*}$ indicate statistical significance at the 1,5 , and 10 percent level, respectively.

\begin{tabular}{|c|c|c|c|c|}
\hline & (1) & $(2)$ & $(3)$ & $(4)$ \\
\hline Primary Market & $\begin{array}{c}0.010^{* * *} \\
(0.000)\end{array}$ & $\begin{array}{c}0.010^{* * *} \\
(0.000)\end{array}$ & $\begin{array}{c}0.013^{* * *} \\
(0.000)\end{array}$ & $\begin{array}{c}0.013^{* * *} \\
(0.000)\end{array}$ \\
\hline Jumbo & $\begin{array}{c}-0.015^{* * *} \\
(0.001)\end{array}$ & $\begin{array}{c}-0.018^{* * *} \\
(0.001)\end{array}$ & $\begin{array}{c}-0.025^{* * *} \\
(0.001)\end{array}$ & $\begin{array}{c}-0.027^{* * *} * \\
(0.001)\end{array}$ \\
\hline Primary Market $*$ Jumbo & $\begin{array}{c}0.026^{* * *} \\
(0.001)\end{array}$ & $\begin{array}{c}0.027^{* * *} \\
(0.001)\end{array}$ & $\begin{array}{c}0.026^{* * *} \\
(0.001)\end{array}$ & $\begin{array}{c}0.027^{* * *} \\
(0.001)\end{array}$ \\
\hline \multicolumn{5}{|l|}{ Measure using sand states: } \\
\hline High-Growth Market * Primary market & $\begin{array}{c}0.010^{* * *} \\
(0.001)\end{array}$ & & $\begin{array}{c}0.007^{* * *} \\
(0.001)\end{array}$ & \\
\hline High-Growth Market * Jumbo & $\begin{array}{c}-0.013^{* * *} \\
(0.001)\end{array}$ & & $\begin{array}{c}-0.011^{* * *} \\
(0.001)\end{array}$ & \\
\hline \multicolumn{5}{|l|}{ Measure using constrained areas: } \\
\hline High-Growth Market * Primary market & & $\begin{array}{c}0.009^{* * *} \\
(0.001)\end{array}$ & & $\begin{array}{c}0.008^{* * *} * \\
(0.002)\end{array}$ \\
\hline High-Growth Market * Jumbo & & $\begin{array}{c}-0.011^{* * *} \\
(0.001)\end{array}$ & & $\begin{array}{c}-0.010^{* * *} \\
(0.001)\end{array}$ \\
\hline Applicant and lender controls & Yes & Yes & Yes & Yes \\
\hline Market FE & Yes & Yes & Yes & Yes \\
\hline Lender*Year FE & Yes & Yes & Yes & Yes \\
\hline Cluster at lender-year level & Yes & Yes & Yes & Yes \\
\hline $\mathrm{N}$ & $8,460,571$ & $8,460,571$ & $8,460,571$ & $8,460,571$ \\
\hline$R^{2}$ & 0.397 & 0.397 & 0.392 & 0.392 \\
\hline
\end{tabular}




\section{Table 4b: Within-Lender Test: Expansion to High-Growth Markets}

Notes: This table shows within-lender test for the acceptance rate at lender-market-year level over the period of 1995-2017. Acceptance rates are calculated based on loan number in columns 1-2, and loan volume in columns 3-4. Primary market is dummy that takes the value 1 for the market with the largest share of a lender in a year. Jumbo is a dummy that takes the value 1 for the jumbo segment. Local lender is a dummy that takes the value 1 for lenders with 25 percent or more of total lending in high-growth markets. High-growth markets are measured by Sand States (Arizona, California, Florida, and Nevada) or constrained areas, defined as areas with land availability in the bottom decile according to Lutz and Sand (2019). Applicant controls include the share of loans with full documentation, the share of women applicants, and share of minority applicants. Lender controls include the log of total assets, Tier 1 capital ratio, and deposit to asset ratio. We also include lender $\times$ year fixed effects. Standard errors clustered at the lender-year level are in parentheses. ${ }^{* * *},{ }^{* *}$, and ${ }^{*}$ indicate statistical significance at the 1,5 , and 10 percent level, respectively.

\begin{tabular}{|c|c|c|c|c|}
\hline & $(1)$ & $(2)$ & $(3)$ & (4) \\
\hline Primary Market & $\begin{array}{c}0.012^{* * *} \\
(0.000)\end{array}$ & $\begin{array}{c}0.012^{* * *} \\
(0.000)\end{array}$ & $\begin{array}{c}0.015^{* * *} \\
(0.000)\end{array}$ & $\begin{array}{c}0.015^{* * *} \\
(0.000)\end{array}$ \\
\hline Jumbo & $\begin{array}{c}-0.008^{* * *} \\
(0.001)\end{array}$ & $\begin{array}{c}-0.012^{* * *} \\
(0.001)\end{array}$ & $\begin{array}{c}-0.018^{* * *} \\
(0.001)\end{array}$ & $\begin{array}{c}-0.021^{* * *} \\
(0.001)\end{array}$ \\
\hline Primary Market * Jumbo & $\begin{array}{c}0.020^{* * *} \\
(0.001)\end{array}$ & $\begin{array}{c}0.021^{* * *} \\
(0.001)\end{array}$ & $\begin{array}{c}0.021^{* * *} \\
(0.001)\end{array}$ & $\begin{array}{c}0.022^{* * *} \\
(0.001)\end{array}$ \\
\hline Measure using sand states: & & & & \\
\hline High-Growth Market & $\begin{array}{c}0.015^{* * *} \\
(0.001)\end{array}$ & & $\begin{array}{c}0.013^{* * *} \\
(0.001)\end{array}$ & \\
\hline High-Growth Market * Primary market & $\begin{array}{c}0.007^{* * *} \\
(0.001)\end{array}$ & & $\begin{array}{c}0.005^{* * *} \\
(0.001)\end{array}$ & \\
\hline High-Growth Market * Jumbo & $\begin{array}{c}-0.018^{* * *} \\
(0.001)\end{array}$ & & $\begin{array}{c}-0.015^{* * *} \\
(0.001)\end{array}$ & \\
\hline Measure using constrained areas: & & & & \\
\hline High-Growth Market & & $\begin{array}{c}0.001 \\
(0.001)\end{array}$ & & $\begin{array}{c}-0.001 \\
(0.001)\end{array}$ \\
\hline High-Growth Market * Primary market & & $\begin{array}{c}0.009^{* * *} \\
(0.001)\end{array}$ & & $\begin{array}{c}0.008^{* * *} \\
(0.001)\end{array}$ \\
\hline High-Growth Market * Jumbo & & $\begin{array}{c}-0.006^{* * *} \\
(0.001)\end{array}$ & & $\begin{array}{c}-0.005^{* * *} \\
(0.001)\end{array}$ \\
\hline Applicant and lender controls & Yes & Yes & Yes & Yes \\
\hline Market FE & No & No & No & No \\
\hline Lender*Year FE & Yes & Yes & Yes & Yes \\
\hline Cluster at lender-year level & Yes & Yes & Yes & Yes \\
\hline $\mathrm{N}$ & $8,460,571$ & $8,460,571$ & $8,460,571$ & $8,460,571$ \\
\hline$R^{2}$ & 0.393 & 0.393 & 0.388 & 0.388 \\
\hline
\end{tabular}




\section{Table 5: Lender Profitability and Stock Return Volatility}

Notes: This table shows results on lender profitability and stock return volatility over the period of 1995-2017. Return on equity is calculated as the net income to equity ratio. Excess stock return is calculated as the difference between stock return and the 10-year treasury bond yield. Local lender is a dummy that takes the value 1 for lenders with 25 percent or more of total lending in high-growth markets. High-growth markets are measured by Sand States (Arizona, California, Florida, and Nevada) or constrained areas, defined as areas with land availability in the bottom decile according to Lutz and Sand (2019). Lender controls include the log of total assets, Tier 1 capital ratio, and deposit to asset ratio. We also include year fixed effects. Standard errors clustered at the lender level are in parentheses. ${ }^{* * *},{ }^{* *}$, and ${ }^{*}$ indicate statistical significance at the 1 , 5 , and 10 percent level, respectively.

\begin{tabular}{|c|c|c|c|c|c|c|}
\hline & \multicolumn{2}{|c|}{ Return on Equity } & \multicolumn{2}{|c|}{ Stock Return Volatility } & \multicolumn{2}{|c|}{ Excess Return Volatility } \\
\hline Measure using sand states: & & & & & & \\
\hline Exposure to High-Growth Markets & $\begin{array}{l}-0.271 \\
(0.251)\end{array}$ & & $\begin{array}{c}1.877^{* * *} \\
(0.399)\end{array}$ & & $\begin{array}{r}1.857^{* *} \\
(0.396\end{array}$ & \\
\hline Local Lender & $\begin{array}{c}0.046 \\
(0.119)\end{array}$ & & $\begin{array}{c}0.756^{* * *} \\
(0.151)\end{array}$ & & $\begin{array}{r}0.748^{* *} \\
(0.150\end{array}$ & \\
\hline Exposure to HGM * Local Lender & $\begin{array}{l}-0.090 \\
(0.300)\end{array}$ & & $\begin{array}{c}-2.361^{* * *} \\
(0.496)\end{array}$ & & $\begin{array}{r}-2.339^{*} \\
(0.493\end{array}$ & \\
\hline Measure using constrained areas: & & & & & & \\
\hline Exposure to High-Growth Markets & & $\begin{array}{c}-1.081^{* * *} \\
(0.181)\end{array}$ & & $\begin{array}{c}1.744^{* * *} \\
(0.452)\end{array}$ & & $\begin{array}{c}1.718^{* * *} \\
(0.448)\end{array}$ \\
\hline Local Lender & & $\begin{array}{c}-0.354^{* * *} \\
(0.071)\end{array}$ & & $\begin{array}{l}0.334^{*} \\
(0.174)\end{array}$ & & $\begin{array}{l}0.331^{*} \\
(0.172)\end{array}$ \\
\hline Exposure to HGM * Local Lender & & $\begin{array}{c}1.413^{* * *} \\
(0.222)\end{array}$ & & $\begin{array}{c}-2.214^{* * *} \\
(0.602)\end{array}$ & & $\begin{array}{c}-2.186^{* * *} \\
(0.596)\end{array}$ \\
\hline Lender controls & Yes & Yes & Yes & Yes & Yes & Yes \\
\hline Year FE & Yes & Yes & Yes & Yes & Yes & Yes \\
\hline $\mathrm{N}$ & 69,233 & 69,233 & 8,281 & 8,281 & 8,281 & 8,281 \\
\hline$R^{2}$ & 0.137 & 0.133 & 0.486 & 0.482 & 0.489 & 0.485 \\
\hline
\end{tabular}




\section{Table 6: Lender Systemic Risk}

Notes: This table shows results on systemic risk over the period of 2000-2017. Marginal expected shortfall is defined as the tail expectation of a firm's equity return condition on a market decline. SRISK calculates the firm's expected capital shortfall as a percentage of total assets given its capitalization and marginal expected shortfall. Local lender is a dummy that takes the value 1 for lenders with 25 percent or more of total lending in high-growth markets. High-growth markets are measured by Sand States (Arizona, California, Florida, and Nevada) or constrained areas, defined as areas with land availability in the bottom decile according to Lutz and Sand (2019). Lender controls include the log of total assets, Tier 1 capital ratio, and deposit to asset ratio. We also include year fixed effects. Standard errors clustered at the lender level are in parentheses. ***, ${ }^{* *}$, and * indicate statistical significance at the 1,5 , and 10 percent level, respectively.

\begin{tabular}{lcccc}
\hline & $(1)$ & $(2)$ & $(3)$ & $(4)$ \\
& Marginal Expected Shortfall & SRISK(\%) \\
\hline Measure using sand states: & & & & \\
Exposure to High-Growth Markets & $19.751^{* * *}$ & & -3.215 & \\
& $(6.750)$ & & $(2.319)$ & \\
Local Lender & $12.233^{* * *}$ & & 1.518 & \\
& $(2.669)$ & & $(1.238)$ & \\
Exposure to HGM * Local Lender & $-31.356^{* * *}$ & & 2.916 & \\
& $(7.904)$ & & $(3.490)$ & \\
Measure using constrained areas: & & & & $8.534^{* *}$ \\
Exposure to High-Growth Markets & & $(10.343)$ & & $(3.705)$ \\
& & 5.873 & & 0.898 \\
Local Lender & & $(5.101)$ & & $-9.8094^{*}$ \\
& & -7.721 & & $(5.553)$ \\
Exposure to HGM * Local Lender & & $(13.498)$ & Yes & Yes \\
& Yes & Yes & Yes & Yes \\
Lender controls & Yes & Yes & 759 & 759 \\
Year FE & 759 & 759 & 0.296 & 0.273 \\
\hline $\mathrm{N}$ & 0.534 & 0.494 & & \\
$R^{2}$ & & & & \\
\hline
\end{tabular}




\section{Table 7: Summary Statistics of Mortgage Portfolio}

Notes: This table summarizes mortgage portfolio performance at lender-year level. Portfolio risk is calculated as the standard deviation of the excess return. Return loss is the average return loss by choosing a given portfolio rather than a portfolio combining the benchmark portfolio with cash. Relative Sharpe Ratio loss is one minus the ratio of a given portfolio's Sharpe ratio and the benchmark portfolio's Sharpe ratio.

\begin{tabular}{lcccccc}
\hline & $(1)$ & $(2)$ & $(3)$ & $(4)$ & $(5)$ & $(6)$ \\
Variables & $\mathrm{N}$ & Mean & Std & $\mathrm{p} 10$ & $\mathrm{p} 50$ & $\mathrm{p} 90$ \\
\hline Mortgage portfolio return & 82062 & .0593 & .0358 & .0237 & .0488 & .105 \\
Mortgage portfolio risk & 82062 & .0576 & .0242 & .0344 & .052 & .0916 \\
Return loss & 82062 & .0217 & .0143 & .00829 & .0189 & .0384 \\
Relative Sharpe ratio loss & 82062 & .301 & .189 & .0908 & .262 & .579 \\
\hline
\end{tabular}




\section{Table 8: Mortgage Portfolio Performance}

Notes: This table shows results on mortgage portfolio performance over the period of 1995-2017. Portfolio risk is calculated as the standard deviation of the excess return. Return loss is the average return loss by choosing a given portfolio rather than a portfolio combining the benchmark portfolio with cash. Relative Sharpe Ratio loss is one minus the ratio of a given portfolio's Sharpe ratio and the benchmark portfolio's Sharpe ratio. Local lender is a dummy that takes the value 1 for lenders with 25 percent or more of total lending in high-growth markets. High-growth markets are measured by Sand States (Arizona,

California, Florida, and Nevada) or constrained areas, defined as areas with land availability in the bottom decile according to Lutz and Sand (2019). Lender controls include the log of total assets, Tier 1 capital ratio, and deposit to asset ratio. We also include year fixed effects. Standard errors clustered at the lender level are in parentheses. ${ }^{* * *},{ }^{* *}$, and ${ }^{*}$ indicate statistical significance at the 1,5 , and 10 percent level, respectively.

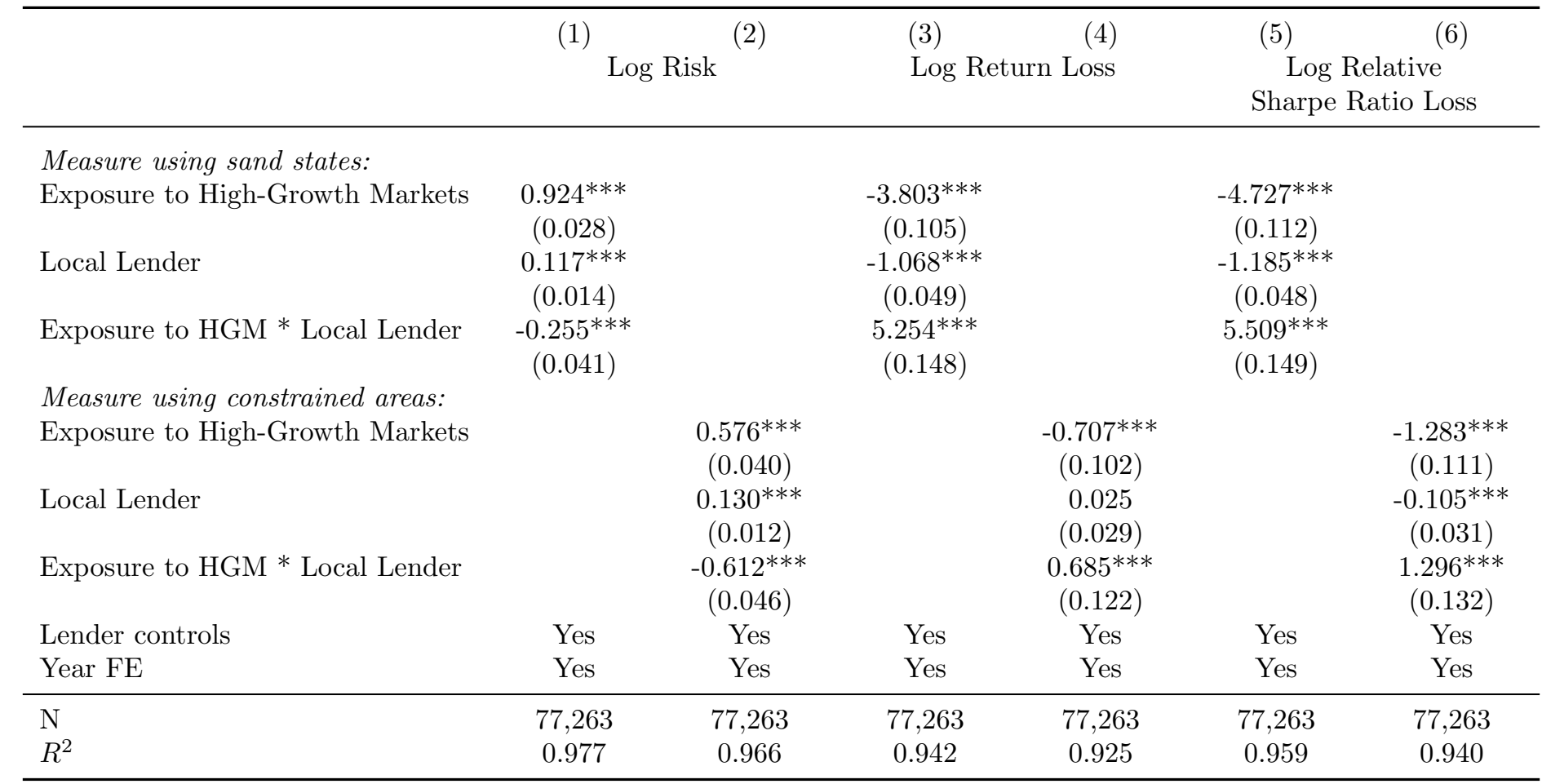




\section{APPENDIX}

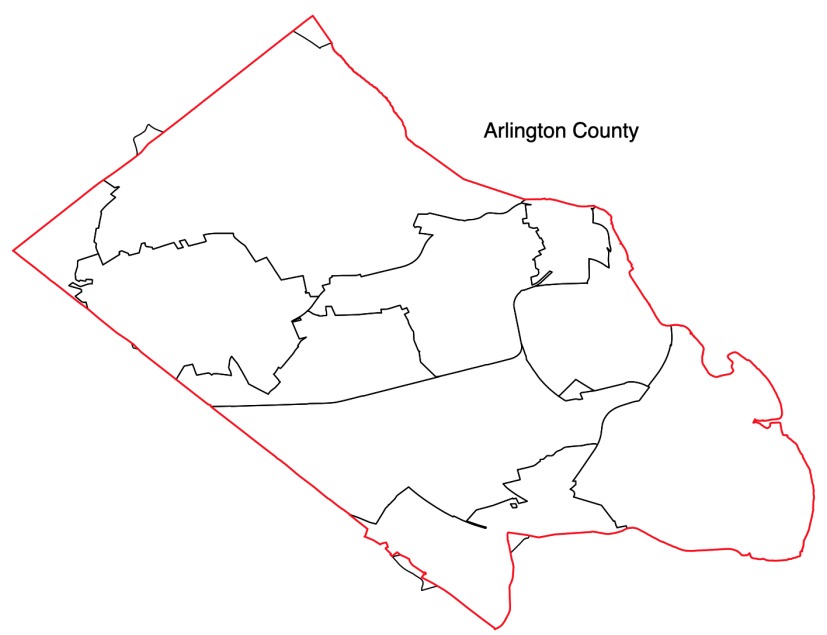

(a) zip $=222$

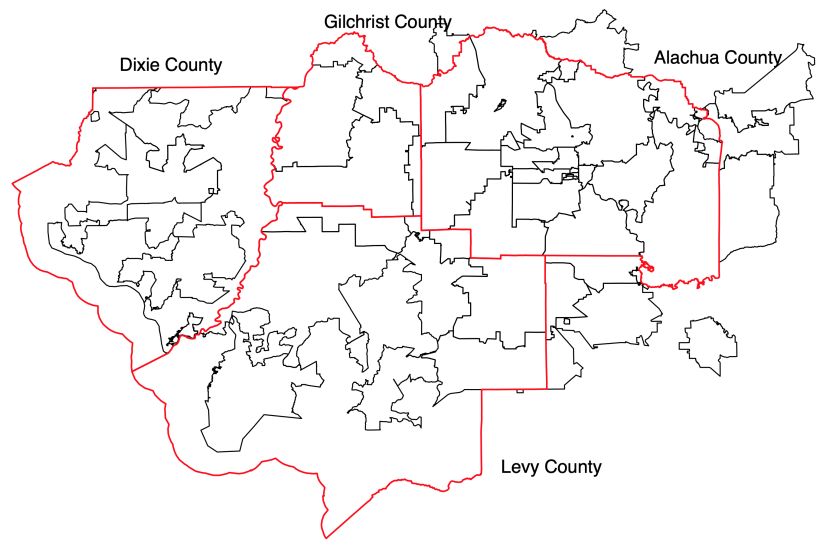

(b) zip $=326$

Figure A1: Linkage Between 3-digit Zip Code and County.

This figure presents example maps of linkage between 3-digit zip code and county. Panel A shows that the zip code 222 matches exactly with Arlington county in Virginia. Panel $\mathrm{B}$ shows that the zip code 326 overlaps with Dixie county, Gilchris county, Alachua county, Levy county in Florida, which is also a Metropolitan Statistical Area (MSA), Gainesville-Lake City, FL. 


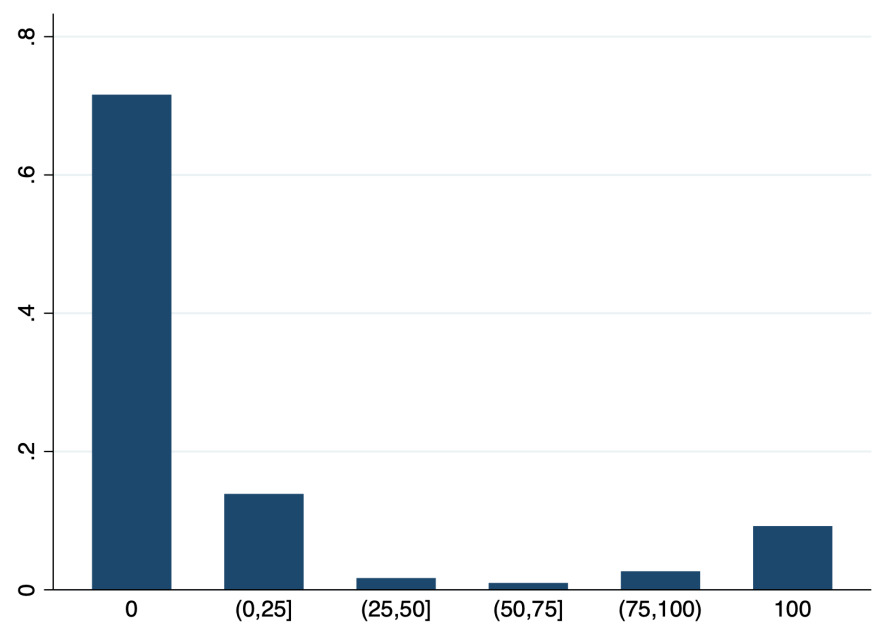

(a) In Sand States

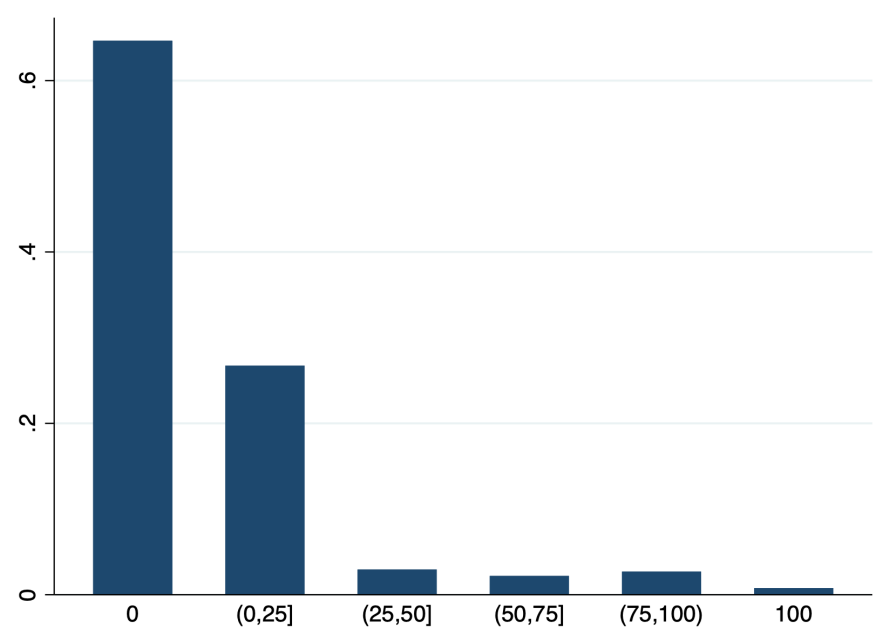

(b) In Constrained Areas

Figure A2: Distribution of Lending to High-Growth Markets.

This figure presents the histogram plot of share of lending to high-growth markets. High-growth markets are measured by Sand States (Arizona, California, Florida, and Nevada) or constrained areas, defined as areas with land availability in the bottom decile according to Lutz and Sand (2019). 


\section{Table A1: Acceptance Rate: Within-Bank Test at County level}

Notes: This table shows within-lender test for the acceptance rate at lender-market-year level over the period of 1995-2017, where a market is defined at

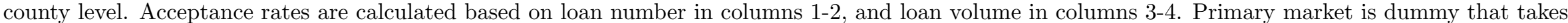

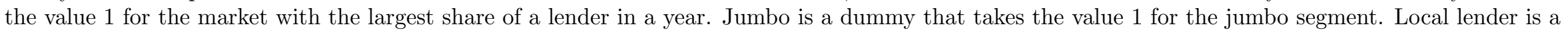
dummy that takes the value 1 for lenders with 25 percent or more of total lending in high-growth markets. High-growth markets are measured by Sand States (Arizona, California, Florida, and Nevada) or constrained areas, defined as areas with land availability in the bottom decile according to Lutz and Sand (2019). Applicant controls include the share of loans with full documentation, the share of women applicants, and share of minority applicants.

Lender controls include the log of total assets, Tier 1 capital ratio, and deposit to asset ratio. We also include market fixed effects and lender $\times$ year fixed

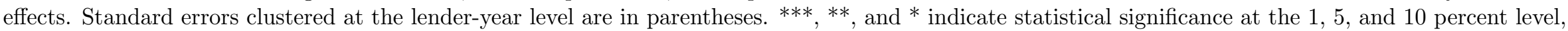
respectively.

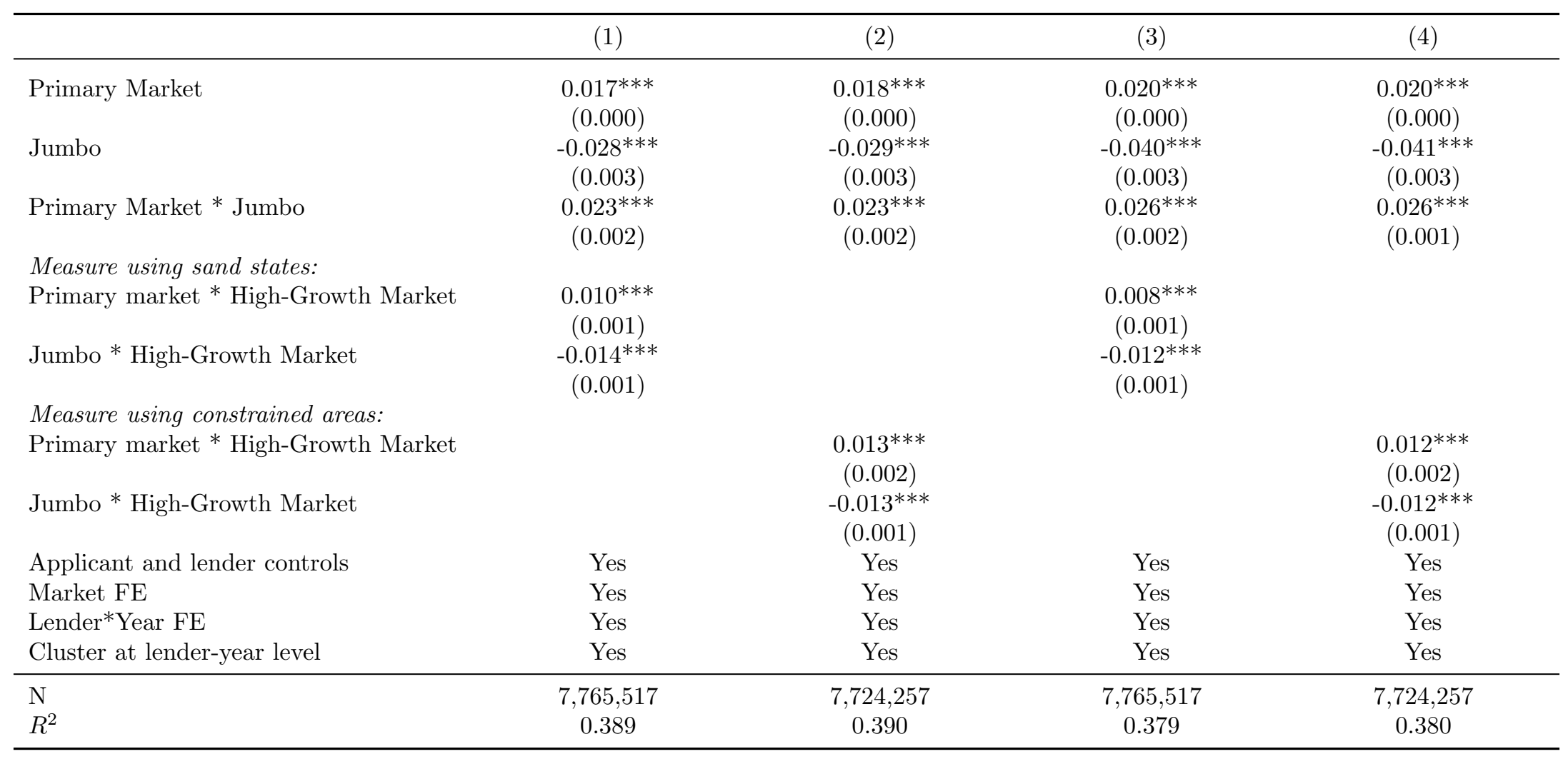




\section{Table A2: Acceptance Rate: Within-Bank Test at MSA level}

Notes: This table shows within-lender test for the acceptance rate at lender-market-year level over the period of 1995-2017, where a market is defined at MSA level. Acceptance rates are calculated based on loan number in columns 1-2, and loan volume in columns 3-4. Primary market is dummy that takes the value 1 for the market with the largest share of a lender in a year. Jumbo is a dummy that takes the value 1 for the jumbo segment. Local lender is a dummy that takes the value 1 for lenders with 25 percent or more of total lending in high-growth markets. High-growth markets are measured by Sand

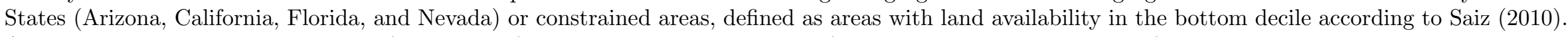
Applicant controls include the share of loans with full documentation, the share of women applicants, and share of minority applicants. Lender controls

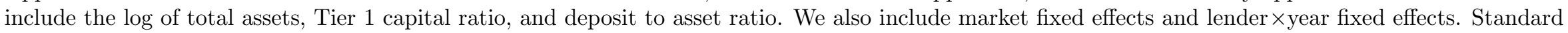
errors clustered at the lender-year level are in parentheses. $* * *, * *$, and $*$ indicate statistical significance at the 1,5 , and 10 percent level, respectively.

\begin{tabular}{|c|c|c|c|c|}
\hline & $(1)$ & $(2)$ & (3) & $(4)$ \\
\hline Primary Market & $\begin{array}{c}0.014^{* * *} \\
(0.001)\end{array}$ & $\begin{array}{c}0.017^{* * *} \\
(0.001)\end{array}$ & $\begin{array}{c}0.018^{* * *} \\
(0.001)\end{array}$ & $\begin{array}{c}0.021^{* * *} \\
(0.001)\end{array}$ \\
\hline Jumbo & $\begin{array}{c}-0.033^{* * *} \\
(0.003)\end{array}$ & $\begin{array}{c}-0.036^{* * *} \\
(0.002)\end{array}$ & $\begin{array}{c}-0.045^{* * *} \\
(0.003)\end{array}$ & $\begin{array}{c}-0.048^{* * *} \\
(0.002)\end{array}$ \\
\hline Primary Market $*$ Jumbo & $\begin{array}{c}0.030^{* * *} \\
(0.002)\end{array}$ & $\begin{array}{c}0.032^{* * *} \\
(0.001)\end{array}$ & $\begin{array}{c}0.032^{* * *} \\
(0.001)\end{array}$ & $\begin{array}{c}0.034^{* * *} \\
(0.001)\end{array}$ \\
\hline \multicolumn{5}{|l|}{ Measure using sand states: } \\
\hline Primary market $*$ High-Growth Market & $\begin{array}{c}0.009 * * * \\
(0.001)\end{array}$ & & $\begin{array}{c}0.006^{* * *} \\
(0.001)\end{array}$ & \\
\hline Jumbo * High-Growth Market & $\begin{array}{c}-0.009^{* * *} \\
(0.001)\end{array}$ & & $\begin{array}{c}-0.006^{* * *} \\
(0.001)\end{array}$ & \\
\hline \multicolumn{5}{|l|}{ Measure using constrained areas: } \\
\hline Primary market ${ }^{*}$ High-Growth Market & & $\begin{array}{c}0.006^{* * *} \\
(0.001)\end{array}$ & & $\begin{array}{c}0.003^{*} \\
(0.001)\end{array}$ \\
\hline Jumbo $*$ High-Growth Market & & $\begin{array}{c}-0.003^{* * *} \\
(0.001)\end{array}$ & & $\begin{array}{l}-0.001 \\
(0.001)\end{array}$ \\
\hline Applicant and lender controls & Yes & Yes & Yes & Yes \\
\hline Market FE & Yes & Yes & Yes & Yes \\
\hline Lender*Year FE & Yes & Yes & Yes & Yes \\
\hline Cluster at lender-year level & Yes & Yes & Yes & Yes \\
\hline $\mathrm{N}$ & $3,865,891$ & $1,998,230$ & $3,865,891$ & $1,998,230$ \\
\hline$R^{2}$ & 0.412 & 0.441 & 0.403 & 0.433 \\
\hline
\end{tabular}


Table A3: Acceptance Rate and Exposure to High-growth Markets (2010-2017)

Notes: This table shows results on the relationship between acceptance rate and exposure to high-growth markets at the lender level over the period of 2010-2017. Panel A (B) reports the results for conforming loans (jumbo loans). Acceptance rates are calculated as the number of accepted applications divided by the total number of applications. High-growth markets are measured by Sand States (Arizona, California, Florida, and Nevada) or constrained areas, defined as areas with land availability in the bottom decile according to Lutz and Sand (2019). Applicant controls include the share of loans with full documentation, the share of women applicants, and share of minority applicants. Lender controls include the log of total assets, Tier 1 capital ratio, and deposit to asset ratio. We also include year fixed effects. Standard errors clustered at the lender level are in parentheses. ${ }^{* * *},{ }^{* *}$, and ${ }^{*}$ indicate statistical significance at the 1,5 , and 10 percent level, respectively.

\begin{tabular}{|c|c|c|c|c|}
\hline & $(1)$ & $(2)$ & $(3)$ & $(4)$ \\
\hline \multicolumn{5}{|l|}{ Panel A: Conforming Loans } \\
\hline Exposure to High-Growth Markets (sand states) & $\begin{array}{c}-0.031^{* * *} \\
(0.007)\end{array}$ & & $\begin{array}{c}-0.042^{* * *} \\
(0.007)\end{array}$ & \\
\hline Exposure to High-Growth Markets (constrained areas) & & $\begin{array}{c}-0.025^{* * *} \\
(0.009)\end{array}$ & & $\begin{array}{c}-0.029^{* * *} \\
(0.009)\end{array}$ \\
\hline Applicant controls & No & No & Yes & Yes \\
\hline Lender controls & Yes & Yes & Yes & Yes \\
\hline Year FE & Yes & Yes & Yes & Yes \\
\hline $\mathrm{N}$ & 27,856 & 27,856 & 27,325 & 27,325 \\
\hline$R^{2}$ & 0.040 & 0.037 & 0.083 & 0.078 \\
\hline \multicolumn{5}{|l|}{ Panel B: Jumbo Loans } \\
\hline Exposure to High-Growth Markets (sand states) & $\begin{array}{c}-0.047^{* * *} \\
(0.007)\end{array}$ & & $\begin{array}{c}-0.056^{* * *} \\
(0.007)\end{array}$ & \\
\hline Exposure to High-Growth Markets (constrained areas) & & $\begin{array}{c}-0.041^{* * *} \\
(0.010)\end{array}$ & & $\begin{array}{c}-0.044^{* * *} \\
(0.010)\end{array}$ \\
\hline Applicant controls & No & No & Yes & Yes \\
\hline Lender controls & Yes & Yes & Yes & Yes \\
\hline Year FE & Yes & Yes & Yes & Yes \\
\hline $\mathrm{N}$ & 23,631 & 23,631 & 20,190 & 20,190 \\
\hline$R^{2}$ & 0.025 & 0.023 & 0.040 & 0.036 \\
\hline
\end{tabular}




\section{Table A4a: Acceptance Rate of Local and Nonlocal Lenders, Conforming Loans (2010-2017)}

Notes: This table shows results on the relationship between acceptance rate of conforming loans and exposure to high-growth markets over the period of 2010-2017. Acceptance rates are calculated as the number of accepted applications divided by the total number of applications. Local lender in

high-growth markets is defined as those with 25 percent or more of total lending in those markets. High-growth markets are measured by Sand States (Arizona, California, Florida, and Nevada) or constrained areas, defined as areas with land availability in the bottom decile according to Lutz and Sand (2019). Applicant controls include the share of loans with full documentation, the share of women applicants, and share of minority applicants. Lender controls include the log of total assets, Tier 1 capital ratio, and deposit to asset ratio. We also include year fixed effects. Standard errors clustered at the lender level are in parentheses. ${ }^{* *},{ }^{* *}$, and $*^{*}$ indicate statistical significance at the 1,5 , and 10 percent level, respectively.

\begin{tabular}{|c|c|c|c|c|}
\hline & $(1)$ & $(2)$ & $(3)$ & $(4)$ \\
\hline \multicolumn{5}{|l|}{ Measure using sand states: } \\
\hline Exposure to High-Growth Markets & $\begin{array}{l}-0.068 \\
(0.048)\end{array}$ & & $\begin{array}{c}-0.063 \\
(0.045)\end{array}$ & \\
\hline Local Lender & $\begin{array}{l}-0.007 \\
(0.018)\end{array}$ & & $\begin{array}{l}-0.001 \\
(0.017)\end{array}$ & \\
\hline Exposure to HGM * Local Lender & $\begin{array}{c}0.044 \\
(0.055)\end{array}$ & & $\begin{array}{c}0.022 \\
(0.053)\end{array}$ & \\
\hline \multicolumn{5}{|l|}{ Measure using constrained areas: } \\
\hline Exposure to High-Growth Markets & & $\begin{array}{c}-0.119^{* * *} \\
(0.038)\end{array}$ & & $\begin{array}{c}-0.127^{* * *} \\
(0.038)\end{array}$ \\
\hline \multirow[t]{2}{*}{ Local Lender } & & $-0.024^{*}$ & & -0.019 \\
\hline & & $(0.014)$ & & $(0.014)$ \\
\hline \multirow[t]{2}{*}{ Exposure to HGM * Local Lender } & & $0.127^{* * *}$ & & $0.124^{* * *}$ \\
\hline & & $(0.046)$ & & $(0.046)$ \\
\hline Applicant controls & No & No & Yes & Yes \\
\hline Lender controls & Yes & Yes & Yes & Yes \\
\hline Year FE & Yes & Yes & Yes & Yes \\
\hline $\mathrm{N}$ & 28,030 & 28,030 & 27,498 & 27,498 \\
\hline$R^{2}$ & 0.038 & 0.036 & 0.082 & 0.077 \\
\hline
\end{tabular}


Table A4b: Acceptance Rate of Local and Nonlocal Lenders, Jumbo Loans (2010-2017)

Notes: This table shows results on the relationship between acceptance rate of jumbo loans and exposure to high-growth markets over the period of 2010-2017. Acceptance rates are calculated as the number of accepted applications divided by the total number of applications. Local lender in

high-growth markets is defined as those with 25 percent or more of total lending in those markets. High-growth markets are measured by Sand States (Arizona, California, Florida, and Nevada) or constrained areas, defined as areas with land availability in the bottom decile according to Lutz and Sand (2019). Applicant controls include the share of loans with full documentation, the share of women applicants, and share of minority applicants. Lender controls include the log of total assets, Tier 1 capital ratio, and deposit to asset ratio. We also include year fixed effects. Standard errors clustered at the lender level are in parentheses. ${ }^{* *}, * *$, and $*$ indicate statistical significance at the 1,5 , and 10 percent level, respectively.

\begin{tabular}{|c|c|c|c|c|}
\hline & $(1)$ & $(2)$ & $(3)$ & $(4)$ \\
\hline \multicolumn{5}{|l|}{ Measure using sand states: } \\
\hline Exposure to High-Growth Markets & $\begin{array}{c}-0.344^{* * *} \\
(0.073)\end{array}$ & & $\begin{array}{c}-0.387^{* * *} \\
(0.075)\end{array}$ & \\
\hline Local Lender & $\begin{array}{c}-0.057^{* *} \\
(0.023)\end{array}$ & & $\begin{array}{c}-0.063^{* * *} \\
(0.024)\end{array}$ & \\
\hline Exposure to HGM $*$ Local Lender & $\begin{array}{c}0.357^{* * *} \\
(0.082)\end{array}$ & & $\begin{array}{c}0.399^{* * *} \\
(0.085)\end{array}$ & \\
\hline \multicolumn{5}{|l|}{ Measure using constrained areas: } \\
\hline Exposure to High-Growth Markets & & $\begin{array}{c}-0.185^{* * *} \\
(0.043)\end{array}$ & & $\begin{array}{c}-0.223^{* * *} \\
(0.045)\end{array}$ \\
\hline Local Lender & & $\begin{array}{c}-0.040^{* *} \\
(0.016)\end{array}$ & & $\begin{array}{c}-0.046^{* * *} \\
(0.016)\end{array}$ \\
\hline Exposure to HGM $*$ Local Lender & & $\begin{array}{c}0.202^{* * *} \\
(0.051)\end{array}$ & & $\begin{array}{c}0.248^{* * *} \\
(0.053)\end{array}$ \\
\hline Applicant controls & No & No & Yes & Yes \\
\hline Lender controls & Yes & Yes & Yes & Yes \\
\hline Year FE & Yes & Yes & Yes & Yes \\
\hline $\mathrm{N}$ & 23,760 & 23,760 & 20,312 & 20,312 \\
\hline$R^{2}$ & 0.028 & 0.024 & 0.044 & 0.038 \\
\hline
\end{tabular}


Table A5a: Acceptance Rate: Within-Lender Test (2010-2017)

Notes: This table shows within-lender test for the acceptance rate at lender-market-year level over the period of 2010-2017. Acceptance rates are calculated based on loan number in columns 1-2, and loan volume in columns 3-4. Primary market is dummy that takes the value 1 for the market with the largest share of a lender in a year. Jumbo is a dummy that takes the value 1 for the jumbo segment. Local lender is a dummy that takes the value 1 for lenders with 25 percent or more of total lending in high-growth markets. High-growth markets are measured by Sand States (Arizona, California, Florida, and Nevada) or constrained areas, defined as areas with land availability in the bottom decile according to Lutz and Sand (2019). Applicant controls include the share of loans with full documentation, the share of women applicants, and share of minority applicants. Lender controls include the log of total assets, Tier 1 capital ratio, and deposit to asset ratio. We also include market fixed effects and lender $\times$ year fixed effects. Standard errors clustered at the lender-year level are in parentheses. ${ }^{* *}, * *$, and $*$ indicate statistical significance at the 1,5 , and 10 percent level, respectively.

\begin{tabular}{|c|c|c|c|c|}
\hline & (1) & $(2)$ & (3) & (4) \\
\hline Primary Market & $\begin{array}{c}0.007^{* * *} \\
(0.001)\end{array}$ & $\begin{array}{c}0.007^{* * *} \\
(0.001)\end{array}$ & $\begin{array}{c}0.010^{* * *} \\
(0.001)\end{array}$ & $\begin{array}{c}0.011^{* * *} \\
(0.001)\end{array}$ \\
\hline Jumbo & $\begin{array}{c}-0.033^{* * *} \\
(0.002)\end{array}$ & $\begin{array}{c}-0.038^{* * * *} \\
(0.002)\end{array}$ & $\begin{array}{c}-0.042^{* * * *} \\
(0.002)\end{array}$ & $\begin{array}{c}-0.047^{* * *} \\
(0.002)\end{array}$ \\
\hline Primary Market * Jumbo & $\begin{array}{c}0.040^{* * *} \\
(0.002)\end{array}$ & $\begin{array}{c}0.043^{* * *} \\
(0.002)\end{array}$ & $\begin{array}{c}0.042^{* * *} \\
(0.002)\end{array}$ & $\begin{array}{c}0.044^{* * *} \\
(0.002)\end{array}$ \\
\hline Measure using sand states: & & & & \\
\hline High-Growth Market * Primary market & $\begin{array}{c}0.012^{* * *} \\
(0.002)\end{array}$ & & $\begin{array}{c}0.009^{* * *} \\
(0.002)\end{array}$ & \\
\hline High-Growth Market * Jumbo & $\begin{array}{c}-0.024^{* * *} \\
(0.002)\end{array}$ & & $\begin{array}{c}-0.022^{* * *} \\
(0.002)\end{array}$ & \\
\hline Measure using constrained areas: & & & & \\
\hline High-Growth Market * Primary market & & $\begin{array}{c}0.008^{* * *} \\
(0.003)\end{array}$ & & $\begin{array}{c}0.007^{* *} \\
(0.003)\end{array}$ \\
\hline High-Growth Market * Jumbo & & $\begin{array}{c}-0.016^{* * *} \\
(0.002)\end{array}$ & & $\begin{array}{c}-0.014^{* * *} \\
(0.002)\end{array}$ \\
\hline Applicant and lender controls & Yes & Yes & Yes & Yes \\
\hline Market FE & Yes & Yes & Yes & Yes \\
\hline Lender*Year FE & Yes & Yes & Yes & Yes \\
\hline Cluster at lender-year level & Yes & Yes & Yes & Yes \\
\hline $\mathrm{N}$ & $2,855,791$ & $2,855,791$ & $2,855,791$ & $2,855,791$ \\
\hline$R^{2}$ & 0.307 & 0.307 & 0.300 & 0.300 \\
\hline
\end{tabular}


Table A5b: Within-Lender Test: Expansion to High-Growth Markets (2010-2017)

Notes: This table shows within-lender test for the acceptance rate at lender-market-year level over the period of 2010-2017. Acceptance rates are calculated based on loan number in columns 1-2, and loan volume in columns 3-4. Primary market is dummy that takes the value 1 for the market with the largest share of a lender in a year. Jumbo is a dummy that takes the value 1 for the jumbo segment. Local lender is a dummy that takes the value 1 for lenders with 25 percent or more of total lending in high-growth markets. High-growth markets are measured by Sand States (Arizona, California, Florida, and Nevada) or constrained areas, defined as areas with land availability in the bottom decile according to Lutz and Sand (2019). Applicant controls include the share of loans with full documentation, the share of women applicants, and share of minority applicants. Lender controls include the log of total assets, Tier 1 capital ratio, and deposit to asset ratio. We also include lender $\times$ year fixed effects. Standard errors clustered at the lender-year level are in parentheses. ${ }^{* * *},{ }^{* *}$, and ${ }^{*}$ indicate statistical significance at the 1,5 , and 10 percent level, respectively.

\begin{tabular}{|c|c|c|c|c|}
\hline & (1) & $(2)$ & (3) & (4) \\
\hline Primary Market & $\begin{array}{c}0.010^{* * *} \\
(0.001)\end{array}$ & $\begin{array}{c}0.009^{* * *} \\
(0.001)\end{array}$ & $\begin{array}{c}0.013^{* * *} \\
(0.001)\end{array}$ & $\begin{array}{c}0.013^{* * *} \\
(0.001)\end{array}$ \\
\hline Jumbo & $\begin{array}{c}-0.028^{* * *} \\
(0.002)\end{array}$ & $\begin{array}{c}-0.034^{* * *} \\
(0.002)\end{array}$ & $\begin{array}{c}-0.037 * * * \\
(0.002)\end{array}$ & $\begin{array}{c}-0.043^{* * *} \\
(0.002)\end{array}$ \\
\hline Primary Market * Jumbo & $\begin{array}{c}0.036^{* * *} \\
(0.002)\end{array}$ & $\begin{array}{c}0.040 * * * \\
(0.002)\end{array}$ & $\begin{array}{c}0.037^{* * *} \\
(0.002)\end{array}$ & $\begin{array}{c}0.041^{* * *} \\
(0.002)\end{array}$ \\
\hline \multicolumn{5}{|l|}{ Measure using sand states: } \\
\hline High-Growth Market & $\begin{array}{c}0.006^{* * *} \\
(0.001)\end{array}$ & & $\begin{array}{c}0.003^{* *} \\
(0.001)\end{array}$ & \\
\hline High-Growth Market * Primary market & $\begin{array}{c}0.008^{* * *} \\
(0.002)\end{array}$ & & $\begin{array}{c}0.005^{* * *} \\
(0.002)\end{array}$ & \\
\hline High-Growth Market * Jumbo & $\begin{array}{c}-0.027^{* * *} \\
(0.002)\end{array}$ & & $\begin{array}{c}-0.025^{* * *} \\
(0.002)\end{array}$ & \\
\hline \multicolumn{5}{|l|}{ Measure using constrained areas: } \\
\hline High-Growth Market & & $\begin{array}{c}0.000 \\
(0.001)\end{array}$ & & $\begin{array}{c}-0.002^{*} \\
(0.001)\end{array}$ \\
\hline High-Growth Market * Primary market & & $\begin{array}{c}0.008^{* * *} \\
(0.003)\end{array}$ & & $\begin{array}{c}0.006^{* *} \\
(0.003)\end{array}$ \\
\hline High-Growth Market * Jumbo & & $\begin{array}{c}-0.011^{* * *} \\
(0.002)\end{array}$ & & $\begin{array}{c}-0.010^{* * *} \\
(0.002)\end{array}$ \\
\hline Applicant and lender controls & Yes & Yes & Yes & Yes \\
\hline Market FE & No & No & No & No \\
\hline Lender*Year FE & Yes & Yes & Yes & Yes \\
\hline Cluster at lender-year level & Yes & Yes & Yes & Yes \\
\hline $\mathrm{N}$ & $2,855,791$ & $2,855,791$ & $2,855,791$ & $2,855,791$ \\
\hline$R^{2}$ & 0.303 & 0.302 & 0.296 & 0.295 \\
\hline
\end{tabular}




\section{Table A6: Lender Profitability and Stock Return Volatility (2010-2017)}

Notes: This table shows results on lender profitability and stock return volatility over the period of 2010-2017. Return on equity is calculated as the net income to equity ratio. Excess stock return is calculated as the difference between stock return and the 10-year treasury bond yield. Local lender is a dummy that takes the value 1 for lenders with 25 percent or more of total lending in high-growth markets. High-growth markets are measured by Sand States (Arizona, California, Florida, and Nevada) or constrained areas, defined as areas with land availability in the bottom decile according to Lutz and Sand (2019). Lender controls include the log of total assets, Tier 1 capital ratio, and deposit to asset ratio. We also include year fixed effects. Standard errors clustered at the lender level are in parentheses. ${ }^{* * *},{ }^{* *}$, and ${ }^{*}$ indicate statistical significance at the 1,5 , and 10 percent level, respectively.

\begin{tabular}{|c|c|c|c|c|c|c|}
\hline & (1) & $(2)$ & $(3)$ & $(4)$ & $(5)$ & $(6)$ \\
\hline & \multicolumn{2}{|c|}{ Return on Equity } & \multicolumn{2}{|c|}{ Stock Return Volatility } & \multicolumn{2}{|c|}{ Excess Return Volatility } \\
\hline \multicolumn{7}{|l|}{ Measure using sand states: } \\
\hline Exposure to High-Growth Markets & $\begin{array}{l}-0.100 \\
(0.334)\end{array}$ & & $\begin{array}{c}1.621^{* * *} \\
(0.599)\end{array}$ & & $\begin{array}{c}1.624^{* * *} \\
(0.599)\end{array}$ & \\
\hline Local Lender & $\begin{array}{c}0.184 \\
(0.114)\end{array}$ & & $\begin{array}{c}0.844^{* * *} \\
(0.199)\end{array}$ & & $\begin{array}{c}0.844^{* * *} \\
(0.199)\end{array}$ & \\
\hline Exposure to HGM * Local Lender & $\begin{array}{l}-0.504 \\
(0.380)\end{array}$ & & $\begin{array}{c}-2.189^{* * *} \\
(0.692)\end{array}$ & & $\begin{array}{c}-2.192^{* * *} \\
(0.692)\end{array}$ & \\
\hline \multicolumn{7}{|l|}{ Measure using constrained areas: } \\
\hline Exposure to High-Growth Markets & & $\begin{array}{c}-1.228^{* * *} \\
(0.236)\end{array}$ & & $\begin{array}{c}2.279^{* * *} \\
(0.639)\end{array}$ & & $\begin{array}{c}2.281^{* * *} \\
(0.639)\end{array}$ \\
\hline Local Lender & & $\begin{array}{c}-0.367 * * * \\
(0.091)\end{array}$ & & $\begin{array}{c}0.278 \\
(0.217)\end{array}$ & & $\begin{array}{c}0.277 \\
(0.217)\end{array}$ \\
\hline Exposure to HGM * Local Lender & & $\begin{array}{c}1.462^{* * *} \\
(0.290)\end{array}$ & & $\begin{array}{c}-2.900 * * * \\
(0.778)\end{array}$ & & $\begin{array}{c}-2.901^{* * * *} \\
(0.778)\end{array}$ \\
\hline Lender controls & Yes & Yes & Yes & Yes & Yes & Yes \\
\hline Year FE & Yes & Yes & Yes & Yes & Yes & Yes \\
\hline $\mathrm{N}$ & 27,851 & 27,851 & 2,903 & 2,903 & 2,903 & 2,903 \\
\hline$R^{2}$ & 0.079 & 0.073 & 0.324 & 0.321 & 0.324 & 0.320 \\
\hline
\end{tabular}




\section{Table A7: Lender Systemic Risk (2010-2017)}

Notes: This table shows results on systemic risk over the period of 2010-2017. Marginal expected shortfall is defined as the tail expectation of a firm's equity return condition on a market decline. SRISK calculates the firm's expected capital shortfall as a percentage of total assets given its capitalization and marginal expected shortfall. Local lender is a dummy that takes the value 1 for lenders with 25 percent or more of total lending in high-growth markets. High-growth markets are measured by Sand States (Arizona, California, Florida, and Nevada) or constrained areas, defined as areas with land availability in the bottom decile according to Lutz and Sand (2019). Lender controls include the log of total assets, Tier 1 capital ratio, and deposit to asset ratio. We also include year fixed effects. Standard errors clustered at the lender level are in parentheses. ${ }^{* * *}, * *$, and $*$ indicate statistical significance at the 1,5 , and 10 percent level, respectively.

\begin{tabular}{|c|c|c|c|c|}
\hline & \multicolumn{2}{|c|}{ Marginal Expected Shortfall } & \multicolumn{2}{|c|}{ SRISK $(\%)$} \\
\hline Measure using sand states: & & & & \\
\hline Exposure to High-Growth Markets & $\begin{array}{l}8.445 \\
(7.410)\end{array}$ & & $\begin{array}{l}-4.859 \\
(3.903)\end{array}$ & \\
\hline Local Lender & $\begin{array}{c}6.033^{* *} \\
(2.416)\end{array}$ & & $\begin{array}{c}1.220 \\
(1.816)\end{array}$ & \\
\hline Exposure to HGM * Local Lender & $\begin{array}{l}-9.922 \\
(8.541)\end{array}$ & & $\begin{array}{c}6.250 \\
(5.852)\end{array}$ & \\
\hline $\begin{array}{l}\text { Measure using constrained areas: } \\
\text { Exposure to High-Growth Markets }\end{array}$ & & $\begin{array}{c}19.630^{*} \\
(10.388)\end{array}$ & & $\begin{array}{c}14.560^{* *} \\
(6.712)\end{array}$ \\
\hline Local Lender & & $\begin{array}{l}2.799 \\
(9.585)\end{array}$ & & $\begin{array}{c}2.053 \\
(4.799)\end{array}$ \\
\hline Exposure to HGM * Local Lender & & $\begin{array}{l}-15.292 \\
(26.478)\end{array}$ & & $\begin{array}{l}-17.263 \\
(14.686)\end{array}$ \\
\hline Lender controls & Yes & Yes & Yes & Yes \\
\hline Year FE & Yes & Yes & Yes & Yes \\
\hline $\mathrm{N}$ & 394 & 394 & 394 & 394 \\
\hline$R^{2}$ & 0.391 & 0.345 & 0.378 & 0.347 \\
\hline
\end{tabular}

Measure using constrained areas:

Local Lender 
Table A8: Mortgage Portfolio Performance (2010-2017)

Notes: This table shows results on mortgage portfolio performance over the period of 2010-2017. Portfolio risk is calculated as the standard deviation of the excess return. Return loss is the average return loss by choosing a given portfolio rather than a portfolio combining the benchmark portfolio with cash. Relative Sharpe Ratio loss is one minus the ratio of a given portfolio's Sharpe ratio and the benchmark portfolio's Sharpe ratio. Local lender is a dummy that takes the value 1 for lenders with 25 percent or more of total lending in high-growth markets. High-growth markets are measured by Sand States (Arizona, California, Florida, and Nevada) or constrained areas, defined as areas with land availability in the bottom decile according to Lutz and Sand (2019). Lender controls include the log of total assets, Tier 1 capital ratio, and deposit to asset ratio. We also include year fixed effects. Standard errors clustered at the lender level are in parentheses. ${ }^{* * *},{ }^{* *}$, and ${ }^{*}$ indicate statistical significance at the 1,5 , and 10 percent level, respectively.

\begin{tabular}{|c|c|c|c|c|c|c|}
\hline & (1) & $(2)$ & (3) & $(4)$ & $(5)$ & (6) \\
\hline & \multicolumn{2}{|c|}{ Log Risk } & \multicolumn{2}{|c|}{ Log Return Loss } & \multicolumn{2}{|c|}{$\begin{array}{c}\text { Log Relative } \\
\text { Sharpe Ratio Loss }\end{array}$} \\
\hline Measure using sand states: & & & & & & \\
\hline Exposure to High-Growth Markets & $\begin{array}{c}0.965^{* * *} \\
(0.033)\end{array}$ & & $\begin{array}{c}-3.472^{* * *} \\
(0.111)\end{array}$ & & $\begin{array}{c}-4.437^{* * *} \\
(0.120)\end{array}$ & \\
\hline Local Lender & $\begin{array}{c}0.119^{* * *} \\
(0.018)\end{array}$ & & $\begin{array}{c}-1.036^{* * *} \\
(0.061)\end{array}$ & & $\begin{array}{c}-1.156^{* * *} \\
(0.063)\end{array}$ & \\
\hline Exposure to HGM * Local Lender & $\begin{array}{c}-0.279^{* * *} \\
(0.051)\end{array}$ & & $\begin{array}{c}4.855^{* * *} \\
(0.183)\end{array}$ & & $\begin{array}{c}5.134^{* * *} \\
(0.191)\end{array}$ & \\
\hline Measure using constrained areas: & & & & & & \\
\hline Exposure to High-Growth Markets & & $\begin{array}{c}0.549^{* * *} \\
(0.049)\end{array}$ & & $\begin{array}{c}-0.606^{* * *} \\
(0.117)\end{array}$ & & $\begin{array}{c}-1.155^{* * *} \\
(0.127)\end{array}$ \\
\hline Local Lender & & $\begin{array}{c}0.116^{* * *} \\
(0.015)\end{array}$ & & $\begin{array}{c}0.025 \\
(0.036)\end{array}$ & & $\begin{array}{c}-0.091^{* * *} \\
(0.035)\end{array}$ \\
\hline Exposure to HGM $*$ Local Lender & & $\begin{array}{c}-0.565^{* * *} \\
(0.057)\end{array}$ & & $\begin{array}{c}0.590^{* * *} \\
(0.139)\end{array}$ & & $\begin{array}{c}1.155^{* * *} \\
(0.147)\end{array}$ \\
\hline Lender controls & Yes & Yes & Yes & Yes & Yes & Yes \\
\hline Year FE & Yes & Yes & Yes & Yes & Yes & Yes \\
\hline $\mathrm{N}$ & 28,881 & 28,881 & 28,881 & 28,881 & 28,881 & 28,881 \\
\hline$R^{2}$ & 0.981 & 0.971 & 0.951 & 0.935 & 0.964 & 0.946 \\
\hline
\end{tabular}

